\title{
Large Intercalated Neurons of Amygdala Relay Noxious Sensory Information
}

\author{
Thomas C.M. Bienvenu, ${ }^{1}$ Daniela Busti, ${ }^{2}$ Benjamin R. Micklem, ${ }^{1}$ Mahnaz Mansouri, ${ }^{2}$ Peter J. Magill, ${ }^{1}$ \\ Francesco Ferraguti, ${ }^{2}$ and ${ }^{1}$ Marco Capogna ${ }^{1}$ \\ ${ }^{1}$ Medical Research Council Anatomical Neuropharmacology Unit, Department of Pharmacology, University of Oxford, Oxford OX1 3TH, United Kingdom, \\ and ${ }^{2}$ Department of Pharmacology, Medical University of Innsbruck, 6020 Innsbruck, Austria
}

\begin{abstract}
Various GABAergic neuron types of the amygdala cooperate to control principal cell firing during fear-related and other behaviors, and understanding their specialized roles is important. Among GABAergic neurons, the so-called intercalated cells (ITCcs) are critically involved in the expression and extinction of fear memory. Tightly clustered small-sized spiny neurons constitute the majority of ITCcs, but they are surrounded by sparse, larger neurons (L-ITCcs) for which very little information is known. We report here a detailed neurochemical, structural and physiological characterization of rat L-ITCcs, as identified with juxtacellular recording/labeling in vivo. We supplement these data with anatomical and neurochemical analyses of nonrecorded L-ITCcs. We demonstrate that L-ITCcs are GABAergic, and strongly express metabotropic glutamate receptor $1 \alpha$ and $\mathrm{GABA}_{\mathrm{A}}$ receptor $\alpha 1$ subunit, together with moderate levels of parvalbumin. Furthermore, L-ITCcs are innervated by fibers enriched with metabotropic glutamate receptors 7a and/or 8a. In contrast to small-sized spiny ITCcs, L-ITCcs possess thick, aspiny dendrites, have highly branched, long-range axonal projections, and innervate interneurons in the basolateral amygdaloid complex. The axons of L-ITCcs also project to distant brain areas, such as the perirhinal, entorhinal, and endopiriform cortices. In vivo recorded L-ITCcs are strongly activated by noxious stimuli, such as hindpaw pinches or electrical footshocks. Consistent with this, we observed synaptic contacts on L-ITCc dendrites from nociceptive intralaminar thalamic nuclei. We propose that, during salient sensory stimulation, L-ITCcs disinhibit local and distant principal neurons, acting as "hub cells," to orchestrate the activity of a distributed network.
\end{abstract}

Key words: amygdala; GABAergic neurons; juxtacellular recording; metabotropic glutamate receptors; neuroanatomy; somatosensory stimulation

\section{Introduction}

Noxious stimuli recruit neuronal networks to attach emotional significance to coincident neutral stimuli, leading to conditioned fear responses (Pape and Paré, 2010). The neuronal circuits underlying fear learning and memory are currently under intense investigation. This is because fear learning and memory represents a good model for exploring the mechanisms of associative learning (Le-

Received April 2, 2014; revised Nov. 7, 2014; accepted Nov. 13, 2014.

Author contributions: T.C.M.B., F.F., and M.C. designed research; T.C.M.B., D.B., M.M., and F.F. performed research; T.C.M.B., D.B., B.R.M., M.M., P.J.M., F.F., and M.C. analyzed data; T.C.M.B., P.J.M., F.F., and M.C. wrote the paper.

This work was supported by the Medical Research Council to M.C. (award U138197106) and P.J.M. (award U138197109), the Austrian Science Fund (F.F.): I252-B18, P22969-B11 and W12060-10 to F.F., T.C.M.B. was funded by an MRC DPhil studentship, and is a fellow of the Ecole de I'Inserm Liliane Bettencourt MD-PhD Program, France. D.B. was also supported by a NENS studentship. We thank R. Hauer and G. Schmid for their contribution on neuron reconstructions and excellent technical support; antibodies were kindly provided by R. Shigemoto (mGlu7a and mGlu8a), J.-M. Fritschy (GABA $\alpha 1)$, and G. Sperk (SOM).

The authors declare no competing financial interests.

Correspondence should be addressed to either of the following: Marco Capogna, University of Oxford, Department of Pharmacology, Mansfield Road, 0xford 0X13TH, UK, E-mail: marco.capogna@pharm.ox.ac.uk; or Francesco Ferraguti, Department of Pharmacology, Medical University of Innsbruck, Peter Mayr Strasse 1A, 6020 Innsbruck, Austria. E-mail: francesco.ferraguti@i-med.ac.at.

T.C. M. Bienvenu's present address: INSERM U862, Neurocentre Magendie, 146 rue Léo Saignat, 33077 Bordeaux, France.

DOI:10.1523/JNEUROSCI.1323-14.2015

Copyright $\odot 2015$ the authors $\quad 0270-6474 / 15 / 352044-14 \$ 15.00 / 0$
Doux, 2000), and has high translational value for anxiety disorders (Dias et al., 2013). A large body of evidence highlights the involvement in fear learning of a distributed neuronal network that includes at least the amygdala, thalamus, ventromedial prefrontal cortex (mPFC), and hippocampus (Gross and Canteras, 2012).

In the amygdala, the flow of information is gated by multiple parallel pathways involving several types of GABAergic cells (Ehrlich et al., 2009; Capogna, 2014). The highest density of GABAergic neurons is present in the so-called intercalated cell (ITCc) masses, which surround the deep amygdaloid nuclei (Millhouse, 1986). The ITCcs are mostly constituted by tightly clustered spiny GABAergic neurons with small-sized somata (Millhouse, 1986; Royer et al., 1999, 2000). These small-spiny ITCcs have been proposed to gate the transfer of information between fear input and output stations of the amygdala under the control of the mPFC (Pape and Paré, 2010; Duvarci and Paré, 2014). Furthermore, modulation and plasticity of basolateral amygdala (BLA) inputs to small-sized ITCcs has been linked to extinction learning (Jüngling et al., 2008; Amano et al., 2010), whereas the selected lesion of these cells results in a marked deficit in extinction retrieval (Likhtik et al., 2008).

Recent work has demonstrated that small ITCcs might comprise different cell types that project to several intra- and extraamygdala regions (Geracitano et al., 2007; Amir et al., 2011; Busti 
Table 1. Summary of the sources, dilutions, and specificity of primary antibodies

\begin{tabular}{|c|c|c|c|c|}
\hline Primary antibody & Antigen/source & Species & Dilution/procedure & Specificity \\
\hline$C B$ & Recombinant rat calbindin D28k. Swant, Catalog \#CB-38a, Lot no. 9.03 & Rabbit serum & 1:30.000 IF & Manufacturer's technical information \\
\hline ChAT & $\begin{array}{l}\text { Human placental choline acetyltransferase; Chemicon (Millipore), } \\
\text { Catalog \#AB144P }\end{array}$ & Goat $\lg G$ & $1: 100 \mathrm{IF}$ & Wang and Morales, 2009; manufacturer information \\
\hline$C R$ & $\begin{array}{l}\text { Recombinant human calretinin-22 kDa; Swant, Catalog \#0.6B3, } \\
\text { Lot no. } 010399\end{array}$ & Mouse ascites & $1: 20.000 \mathrm{IF}$ & Manufacturer's technical information \\
\hline$C R$ & Recombinant human calretinin; Swant, Catalog \#CG1 & Goat serum & $1: 2.000 \mathrm{IF}$ & Manufacturer's technical information \\
\hline mGlu1 $\alpha$ & $\begin{array}{l}\text { Synthetic peptide (aa 1116-1130, rat sequence); DiaSorin, } \\
\text { Catalog \#24426, Lot no. } 136024\end{array}$ & Rabbit lgG & 1:500 IF & Ferraguti et al., 2004 \\
\hline mGlu1 $\alpha$ & $\begin{array}{l}\text { Fusion protein (aa 945-1127, mouse sequence); Frontier Sciences, } \\
\text { Catalog \#mGluR1a-GP-Af660 }\end{array}$ & G. Pig lgG & $1: 500 \mathrm{IF}+\mathrm{LM}+\mathrm{EM}$ & Tanaka et al., 2000 \\
\hline mGlu8a & $\begin{array}{l}\text { Synthetic peptide (last } 23 \text { aa, mouse sequence); kindly provided } \\
\text { by Prof Shigemoto (NIPS, Okazaki, Japan) }\end{array}$ & G. Pig lgG & $1 \mu \mathrm{g} / \mathrm{ml} \mathrm{IF}+\mathrm{EM}$ & Ferraguti et al., 2005 \\
\hline mGlu7a & $\begin{array}{l}\text { Bacterial fusion protein (aa } 874-915 \text {, rat sequence); kindly provided } \\
\text { by Prof Shigemoto }\end{array}$ & Rabbit lgG & $1 \mu \mathrm{g} / \mathrm{ml} \mathrm{IF}+\mathrm{EM}$ & Shigemoto et al., 1997 \\
\hline $\mathrm{GABA}_{\mathrm{A}} \alpha 1$ & $\begin{array}{l}\text { Kindly provided by Prof Fritschy (Dept Pharmacology, University } \\
\text { of Zurich, Switzerland) }\end{array}$ & Rabbit lgG & 1:10.000 IF & Benke et al., 1991 \\
\hline $\mathrm{GABA}_{\mathrm{A}} \alpha 1$ & $\begin{array}{l}\text { Synthetic peptide (aa 369-386, mouse sequence); Frontier Science, } \\
\text { Catalog \#GABARa1-Rb-Af660 }\end{array}$ & Rabbit lgG & $1 \mu \mathrm{g} / \mathrm{ml} \mathrm{IF}$ & Ichikawa et al., 2011 \\
\hline NeuN & $\begin{array}{l}\text { Purified cell nuclei from mouse brain; Chemicon (Millipore), } \\
\text { Catalog \#MAB377, clone A60, Lot no. LV1519148 }\end{array}$ & Mouse lgG & $1: 1.000 \mathrm{IF}$ & Manufacturer's technical information \\
\hline NK1 & $\begin{array}{l}\text { Synthetic peptide (aa 385-407, rat sequence). Chemicon; } \\
\text { Catalog \#AB5060 }\end{array}$ & Rabbit lgG & $1: 1.500 \mathrm{IF}$ & Nakaya et al., 1994 \\
\hline PHA-L & Vector, Catalog \#AS-2300, Lot no. T0403 & Rabbit lgG & $1 \mu \mathrm{g} / \mathrm{ml} \mathrm{IF}+\mathrm{LM}+\mathrm{EM}$ & Manufacturer's technical information \\
\hline PV & Rat muscle PV; Swant; Catalog \#PV-28; Lot no. 5.5 & Rabbit serum & $1: 20.000 \mathrm{IF}+\mathrm{EM}$ & Caillard et al., 2000 \\
\hline PV & $\begin{array}{l}\text { Recombinant full-length rat PV; Synaptic Systems; Catalog } \\
\quad \# 195 \text { 004, Lot no. 195004/1 }\end{array}$ & G. Pig serum & $1: 2.500 \mathrm{IF}$ & Andrioli et al., 2007 \\
\hline SOM & $\begin{array}{l}\text { Recombinant SOM-14 coupled to ovalbumin; Kindly provided by } \\
\text { Prof Sperk (Dept Pharmacology, Innsbruck, Austria) }\end{array}$ & Rabbit lgG & $1: 2.000 \mathrm{IF}$ & Sperk and Widmann, 1985 \\
\hline SOM & $\begin{array}{l}\text { Human somatostatin conjugated to a protein carrier; GeneTex, } \\
\text { Catalog \#GTX 1935, clone SOM-018 }\end{array}$ & Mouse lgG & $1: 250 \mathrm{IF}$ & Lasztóczi et al., 2011 \\
\hline VIP & $\begin{array}{l}\text { Synthetic peptide (aa 1-28) coupled to KLH with glutaraldehyde; } \\
\text { Chemicon, Catalog \#AB1581, Lot no. } 24070740\end{array}$ & Sheep IgG & 1:3.000 IF & Liu et al., 2008 \\
\hline VGAT & $\begin{array}{l}\text { Synthetic peptide (aa 75-87, rat sequence) coupled to keyhole } \\
\text { limpet hemocyanin via an added N-terminal cysteine; } \\
\text { Synaptic Systems, Catalog \#131003 }\end{array}$ & RabbitlgG & 1:500 IF & Garbelli et al., 2008 \\
\hline
\end{tabular}

et al., 2011; Mańko et al., 2011). Furthermore, distinct ITC clusters can be selectively recruited in fear expression or in the retrieval of fear extinction (Whittle et al., 2010; Busti et al., 2011). Previous studies have also suggested the presence of ITCcs with large soma (L-ITCcs) in close proximity to the more common small-spiny ITCcs (Millhouse, 1986; McDonald and Augustine, 1993; Busti et al., 2011; Dobi et al., 2013). However, the detailed structure and function of L-ITCcs have never been reported, and whether they represent a distinct cell type remains unknown.

Here, we define L-ITCcs as a novel cell type, morphologically and molecularly distinct from small ITCcs. We show with juxtacellular recording and labeling of individual neurons in anesthetized rats in vivo that L-ITCcs are GABAergic neurons, which strongly increase their firing upon delivery of noxious stimuli. We further demonstrate that these neurons have an extensive connectivity, long-range axonal projections, and selectively innervate interneurons in the BLA and associative cortices. We propose that L-ITCcs vigorously disinhibit local and distant pyramidal-like neurons and act as "hub cells" (Bonifazi et al., 2009; Quilichini et al., 2012), coordinating distributed network activities during salient sensory stimulation.

\section{Materials and Methods}

Ethical standards and animal experimentation. All procedures involving experimental animals were performed in compliance with the European Convention for the Protection of Vertebrate Animals used for Experi- mental and Other Scientific Purposes (ETS no. 123), the European Communities Council Directive of 24 November 1986 (86/609/EEC), the Animals (Scientific Procedures) Act 1986 (UK) and associated regulations, under approved project and personal licenses by Home Office UK (30/2539 and 70/15536), the Austrian Animal Experimentation Ethics Board (GZ66.011/28-BrGT/2009), and with Society for Neuroscience Policies on the Use of Animals in Neuroscience Research. We further attest that all efforts were made to minimize animal suffering, the number of animals used, and to use alternatives to in vivo techniques whenever available. Experiments were performed on adult male Sprague-Dawley rats $(250-350 \mathrm{~g})$.

In vivo electrophysiological recordings and juxtacellular labeling of neurons. Adult male Sprague-Dawley rats $(250-350 \mathrm{~g})$ were anesthetized with intraperitoneal injections of urethane $(1.30 \mathrm{~g} / \mathrm{kg}$ body weight $)$ plus supplemental doses of ketamine and xylazine, (10-15 and $1-1.5 \mathrm{mg} / \mathrm{kg}$, respectively), as needed. Under strictly controlled anesthesia $\left(37^{\circ} \mathrm{C}\right)$, brain state, as assessed from the electrocorticogram (ECoG) signal, alternates between cortical "activation" (manifested by small amplitude, high-frequency oscillations) and slow-wave activity (large amplitude 1-2 $\mathrm{Hz}$ oscillations with superimposed spindle oscillations). The ECoG was recorded via a $1 \mathrm{~mm}$ diameter steel screw juxtaposed to the slightly punctured dura mater above the right prefrontal cortex (bregma AP: $4.5 \mathrm{~mm}$, ML: $2.0 \mathrm{~mm}$ ), referenced against a screw implanted above the ipsilateral cerebellum. Both screws were secured in position using dental cement (Simplex Rapid, Kemdent). This cortical activity resembles in many ways natural sleep-wake cycles (Clement et al., 2008).

Craniotomies-duratomies were performed over the right amygdala and hippocampus. Unit activity was recorded in the amygdala with elec- 
trodes made of silver-chloride wires loaded in glass pipettes filled with $1.5 \%$ neurobiotin (Vector Laboratories) in $0.5 \mathrm{M} \mathrm{NaCl}(12-22$ $\mathrm{M} \Omega$ resistance in situ, tip diameter $\sim 1.1 \mu \mathrm{m})$. Local field potential of the dorsal (d)CA1 hippocampus and the ECoG were recorded as previously described (Bienvenu et al., 2012). Pinches of $15 \mathrm{~s}$ duration were applied to the left hindpaw using pneumatically driven forceps that delivered a pressure of $183 \mathrm{~g} \times \mathrm{mm}^{-2}$. The transistor-transistor logic (TTL) pulse used to trigger noxious stimuli delivered a nearly immediate footshock, whereas the forceps used for paw pinch required time to close on the paw and to apply sufficient pressure to reach nociceptive threshold. In the latter case, we experimentally estimated that the latency between TTL onset and contact with the paw was 180 ms. This value needs to be taken into account when latencies of the responses to noxious stimuli are evaluated. The firing rates were analyzed in response to 4-6 pinches applied in sequence in each cell. Electrical stimuli (single current pulses of $5 \mathrm{~mA}$ intensity and $2 \mathrm{~ms}$ duration) were delivered at $0.5 \mathrm{~Hz}$ through two wires implanted on the ventral face of the left hindpaw $(>100$ electrical footshocks were given for each cell). All signals were filtered, digitized online at $16.67 \mathrm{kHz}$ and stored on a PC (Bienvenu et al., 2012 provides further details). After recordings, neurons were selectively labeled with neurobiotin by applying anodal current steps at increasing intensities (1-10 nA; $200 \mathrm{~ms}$ duration; 50\% duty cycle) until the firing of the neuron could be robustly modulated by the current injection and then maintained for a few minutes (Pinault, 1996). Spike shape and amplitude were monitored throughout recording and labeling to ensure that the same neuron was recorded and labeled.

Electrophysiological data analysis. All data were analyzed off-line using Spike2 built-in functions and custom scripts (Tukker et al., 2007). Spikes were isolated using thresholds and spike-sorting quality was checked using interspike interval histograms and autocorrelograms. Spike waveforms were obtained by averaging 150 events. Responses to noxious stimuli were assessed by constructing peristimulus histograms (bin size $20 \mathrm{~ms}$ for electrical footshocks, $200 \mathrm{~ms}$ for hindpaw pinches). Responses were analyzed when the brain state (assessed with the ECoG) corresponded to stable activation before, during, and after the noxious stimulus. This allowed for the distinction of sensory-driven responses from effects on the brain state (e.g., switch from slow-wave to activation). We also analyzed responses of neuron tjx24a to footshocks during robust cortical slow-wave activity. The statistical significance of responses was tested using z-score transform thresholds. Z-scores were computed by subtracting the mean baseline firing rate and dividing the result by the baseline SD. Significance was accepted if, in two consecutive bins, the z-score exceeded 1.67 (unilateral test; $p<0.05$ ). Latency was defined as the starting time of the first bin meeting this criterion. Mean firing rates were calculated over $100 \mathrm{~s}$ periods of continuous cortical activated state with concomitant hippocampal theta activity, or during cortical slow-wave activity. Hippocampal theta or gamma
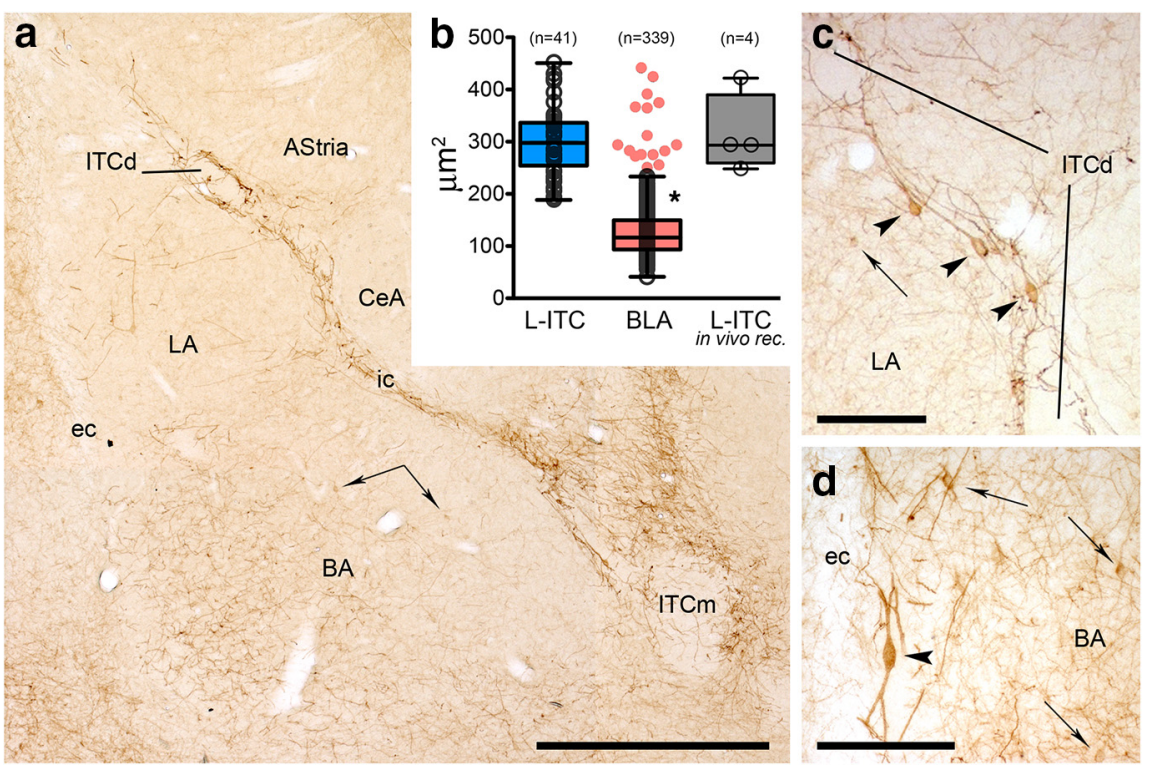

Figure 1. High levels of $\mathrm{mGlu1} \alpha$ receptor immunoreactivity identify L-ITCcs. $\boldsymbol{a}$, Low-magnification composite micrograph displaying $\mathrm{mGlu} 1 \alpha$ immunoreactivity in the rat amygdala. A band of strongly $\mathrm{mGlu} 1 \alpha$-labeled dendrites and somata is clearly visible in association with the intermediate capsule. Additional neurons immunolabeled for mGlu1 $\alpha$ are visible in other amygdaloid areas, including the basolateral complex (arrows). $\boldsymbol{b}$, Tukey whiskers plots (superimposed are individual values shown as empty circles; red dots indicate outliers) of the projected area of the soma of: (blue) strongly labeled mGlu1 $\alpha+$ cells located within or nearby the intermediate or external capsules (L-ITCcs); (red) mGlu1 $\alpha$-labeled cells located within the BLA; (gray) in vivo recorded L-ITCCS. c, Putative L-ITCcs (arrowheads) nearby ITC clusters within the intermediate capsule and (d) external capsule display larger somata and stronger $\mathrm{mGlu1} \alpha$ immunoreactivity compared with other mGlu1 $\alpha+$ neurons nearby (indicated by arrows). Scale bars: $\boldsymbol{a}, 500 \mu \mathrm{m} ; \boldsymbol{c}, \boldsymbol{d}, 150 \mu \mathrm{m}$. BA, Basal nucleus; (eA, central nucleus; ec, external capsule; ic, intermediate capsule; ITCd, dorsomedial intercalated cluster; ITCm, main ITC cluster; LA, lateral nucleus.
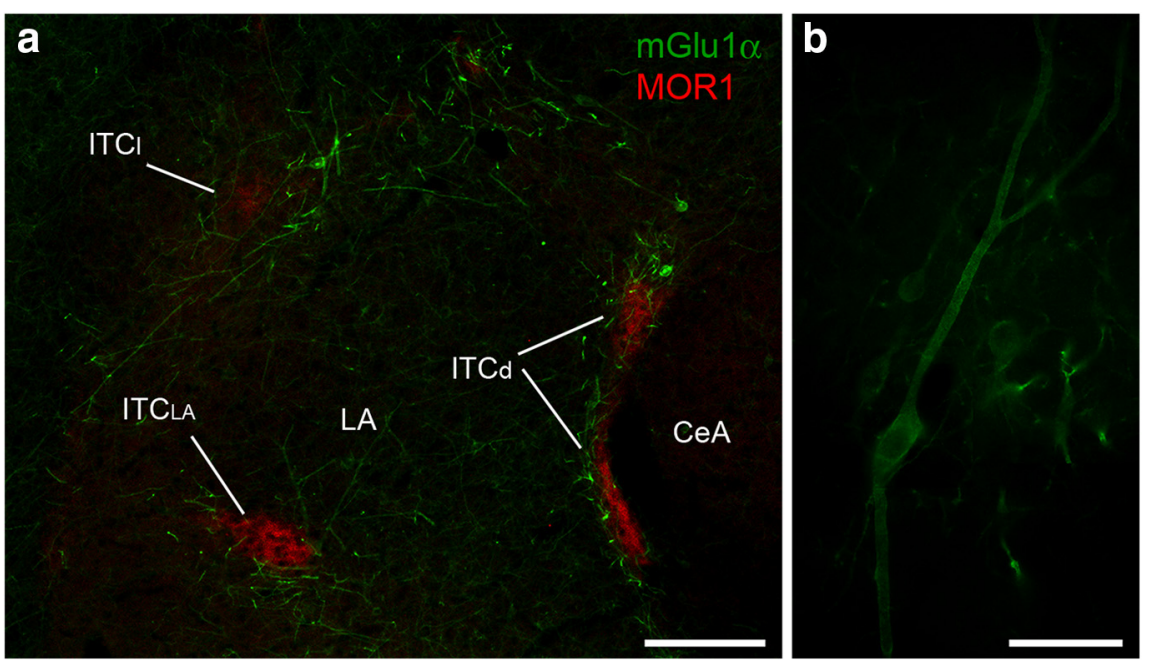

Figure 2. mGlu1 $\alpha+$ L-ITCcs encircle the clusters of small-spiny ITCcs. $\boldsymbol{a}$, Micrograph showing mGlu1 $\alpha+\mathrm{L}-\mathrm{ITC} c$ surrounding ITC clusters immunolabeled for the $\mu$-opioid receptor (MOR1). $\boldsymbol{b}$, Composite micrograph of a representative putative mGlu1 $\alpha+$ L-ITCc characterized by a large ( $>30 \mu \mathrm{m}$ in its longer axis) fusiform soma, and giving rise to thick aspiny primary dendrites. Scale bars: $\boldsymbol{a}, 200 \mu \mathrm{m} ; \boldsymbol{b}, 50 \mu \mathrm{m}$. CeA, Central nucleus; ITCl, lateral intercalated cluster; ITCd, dorsomedial intercalated cluster; ITC intralateral intercalated cluster; $L A$, lateral nucleus.

oscillation analysis and extracellular spike detection were performed as previously described (Bienvenu et al., 2012).

Modulation of amygdala neuron firing in phase with dCA1 theta and gamma oscillations or cortical slow-wave activity (SWA) was tested for significance using the Rayleigh's uniformity test (significance set at $p<0.005$ ). For analysis of neuronal firing relationships with cortical slow oscillations, Rayleigh's tests were performed only after phase nonuniformities of the slow oscillations were corrected 

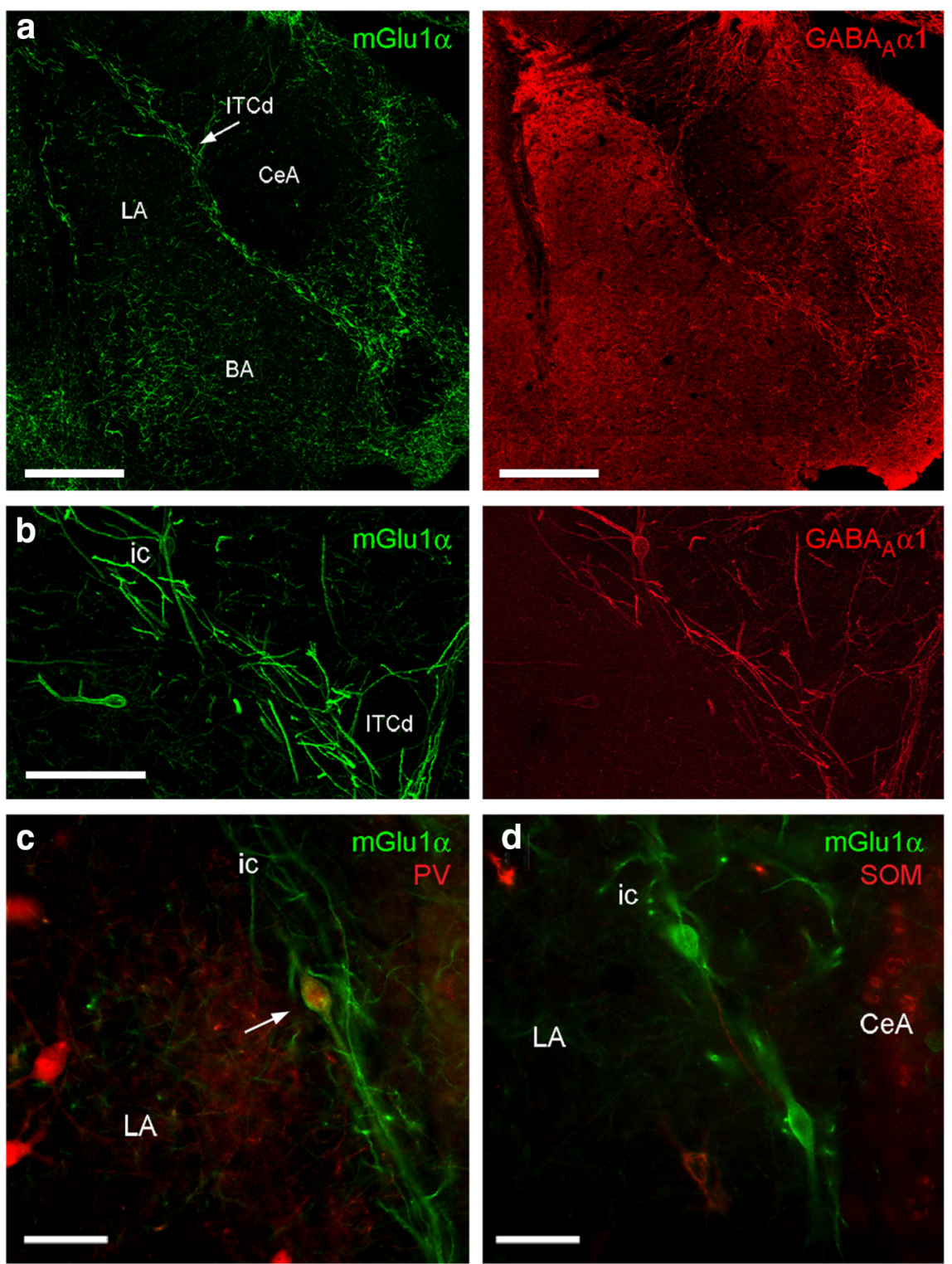

Figure 3. Neurochemical analysis of nonrecorded L-ITCcs. $\boldsymbol{a}$, Low-magnification micrographs depicting the distribution of mGlu1 $\alpha$ (green) and $\mathrm{GABA}_{\mathrm{A}} \alpha 1$ subunit (red) in the amygdala (z-projections of structured illumination). $\boldsymbol{b}$, Higher-magnification of the area containing the dorsomedial ITC cluster (ITCd). All mGlu1 $\alpha+$ L-ITCcs were highly enriched with the GABA $\alpha 1$ subunit. c, A L-ITCC (arrow) strongly immunopositive for mGlu1 $\alpha$ also showed moderate cytoplasmic labeling for PV. $\boldsymbol{d}$, mGlu1 $\alpha+\mathrm{L}$-ITCcs do not express SOM. Scale bars: $\boldsymbol{a}, 400 \mu \mathrm{m} ; \boldsymbol{b}, 100 \mu \mathrm{m} ; \boldsymbol{c}, \boldsymbol{d}, 50 \mu \mathrm{m}$. BA, Basal nucleus; CeA, central nucleus; ic, intermediate capsule; LA, lateral nucleus.

Table 2. Neurochemical markers tested for coexpression with mGlu1 $\alpha+$ in nonrecorded L-ITCcs, by means of double-immunofluorescence experiments

\begin{tabular}{llc}
\hline Markers & No. of mGlu1 $\alpha+$ L-ITCcs analyzed & Colocalization (\%) \\
\hline GABA $_{A} \alpha 1$ & 56 & 100 \\
PV & 69 & $45.0 \pm 6.3$ \\
CB & 42 & 0 \\
CR & 37 & 0 \\
SOM & 43 & 0 \\
NK1 & 49 & 0 \\
VIP & 36 & 0
\end{tabular}

The number of mGlu1 $\alpha+$ L-ITCcs analyzed (i.e. all cells present along the intermediate capsule) is given in the middle column, and was obtained from three rats (3 sections/rat for each marker). CR, Calretinin; NK1, neurokinin 1 receptor; VIP, vasoactive intestinal polypeptide.

with an empirical cumulative distribution function (Siapas et al., 2005).

PHA-L tracing experiments. Rats $(n=7)$ were injected in the posterior intralaminar thalamus (Paxinos and Watson, 2007) with the anterograde tracer Phaseolus vulgaris leucoagglutinin (PHA-L). Anesthesia was induced with isoflurane $4 \%$ and maintained during surgery at $1.5-2 \%$ in air $1.5 \mathrm{~L} / \mathrm{min}$. A solution of $2.5 \%$ $(\mathrm{w} / \mathrm{v})$ PHA-L (Vector Laboratories) in $0.2 \mathrm{M}$ sodium phosphate buffer, $\mathrm{pH}$ 8.0, was injected bilaterally through glass micropipettes (tip diameter $25-50 \mu \mathrm{m}$ ) by iontophoresis (in $\mathrm{mm}$ from bregma: 5.5 posterior, 2.8 medial and lateral, 6.5 ventral) applying square current pulses for 20-40 min (5-10 $\mu \mathrm{A}, 7 \mathrm{~s}$ on/off intervals; Stoelting 51595). After 17-21 d, to allow for PHA-L anterograde transport, rats were deeply anesthetized and perfused transcardially as described in the next section entitled Brain fixation. Brains were serially sectioned in the coronal plane (50 $\mu \mathrm{m}$ thick) including injection sites and the amygdala, using a vibratome (Leica, VT-1000). Every sixth section was used for immunocytochemical detection of PHA-L projections. Data were analyzed only when the injection site was correctly placed and limited to the target area $(n=3$ hemispheres). Little variability in the pattern of terminal labeling was observed among the three correctly placed injections.

Brain fixation. Before perfusions, rats were given a lethal dose of anesthetic, either with ketamine $(\sim 100 \mathrm{mg} / \mathrm{kg}) 1-8 \mathrm{~h}$ after juxtacellular labeling, or with thiopenthal (thiopentone sodium, $100 \mathrm{mg} / \mathrm{kg}$ ). Perfusions were performed via the ascending aorta with $\sim 60 \mathrm{ml}$ of PBS, pH 7.4, followed by $300 \mathrm{ml}$ of fixative containing $4 \% \mathrm{w} / \mathrm{v}$ paraformaldehyde and $15 \% \mathrm{v} / \mathrm{v}$ saturated picric acid, in $\mathrm{PB} 0.1 \mathrm{M}, \mathrm{pH}$ 7.3. For electron microscopy experiments, glutaraldehyde $(0.1 \% \mathrm{v} / \mathrm{v}$ for recorded animals and $0.05 \%$ for control rats) was added to the fixative. After perfusion, brains were immediately dissected out and stored overnight in PBS. They were then cut in 50-to 70- $\mu$ m-thick coronal sections with a vibratome and conserved at $4^{\circ} \mathrm{C}$ in PB $0.1 \mathrm{M}$ containing $0.05 \% \mathrm{NaN}_{3}$ until use.

Light microscopy. All reagents were diluted in PBS or Tris-buffered saline, containing 0.1$0.3 \% \mathrm{v} / \mathrm{v}$ Triton X-100. Neurobiotin-filled neurons were visualized with streptavidin conjugated to a fluorophore (AlexaFluor 405, AlexaFluor 488, Cy5; Jackson Laboratories and Invitrogen). Incubations with primary and secondary antibodies were performed as previously described (Bienvenu et al., 2012; Dobi et al., 2013). Table 1 lists the primary antibodies applied in this study, the concentrations used, and references to studies showing their specificities. Immunofluorescence signals were studied using epifluorescence (Leica DMRB and Zeiss AxioImager M1 microscopes), as well as structured illumination (Apotome system operated with Axiovision software) and confocal microscopy (LSM 710 operated with Zen 2008 software) with an AxioImager Z1 microscope fitted with $40 \times($ NA 1.3) and $63 \times($ NA 1.4) oil-immersion objectives (hardware and software from Carl Zeiss). For confocal imaging, particular care was taken when assessing colocalization of fluorescent signals as previously described (Bienvenu et al., 2012). Brightness and contrast were adjusted for whole image frames with no parts of the frames modified independently in any way.

Assessment of coexpression of various markers with metabotropic glutamate receptor $1 \alpha$-immunopositive $(\operatorname{mGlu} 1 \alpha+)$ L-ITCs was performed manually on all cells located near the medial border of the BLA along the intermediate capsule, after double-immunofluorescence label- 
a
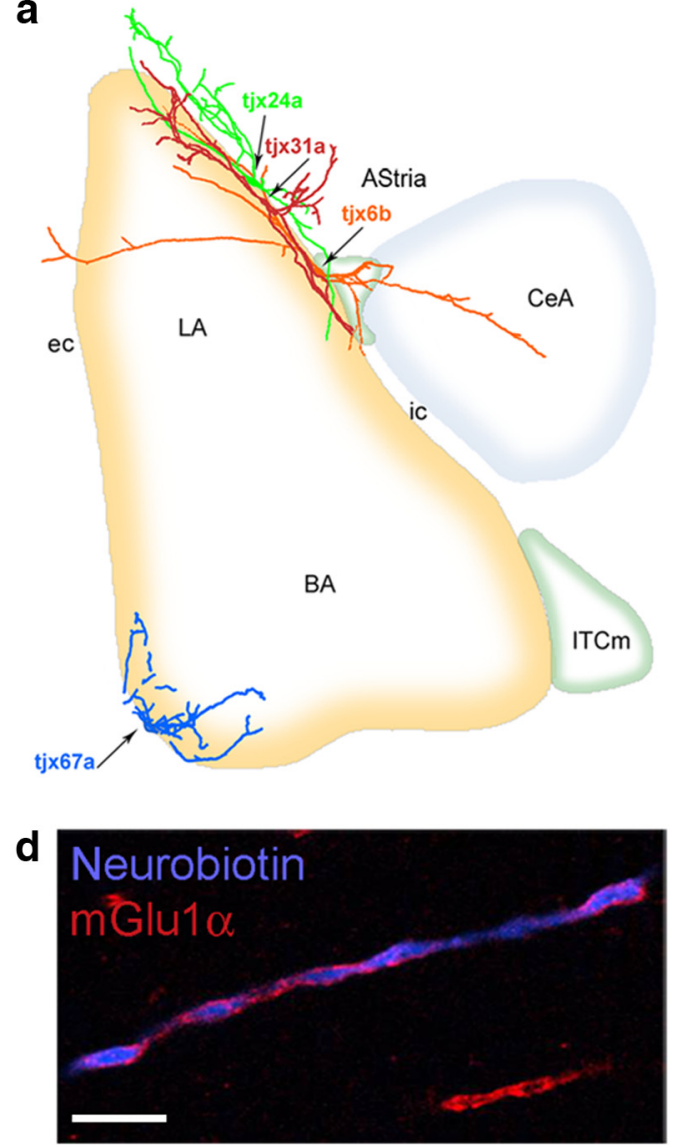

b
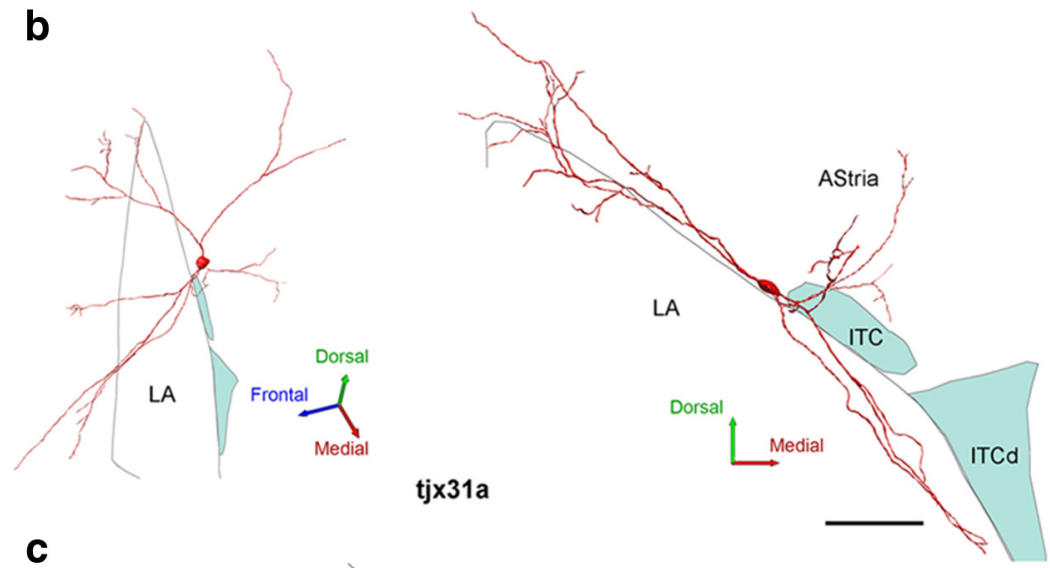

C

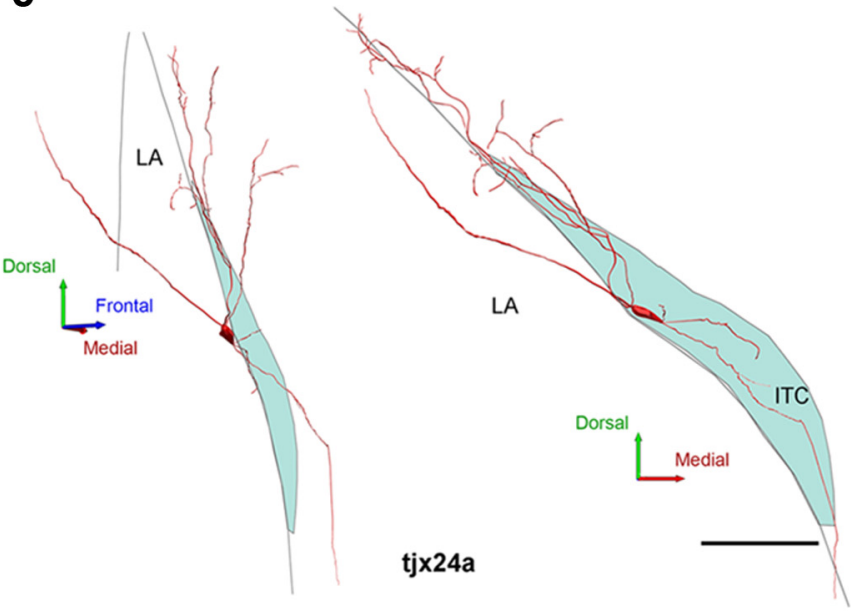

Figure 4. Localization and neurolucida reconstruction of the somatodendritic compartment of recorded L-ITCcs. $\boldsymbol{a}$, Somata and dendrites of recorded L-ITCcs (tjx6b, tjx24a, tjx31a, and tjx67a) in relation to a schematized amygdala. $\boldsymbol{b}$, Left, Top-lateral view of the reconstructed soma and dendrites of an in vivo recorded L-ITCcs (tjx31a); the primary dendrites show a prominent rostral-tocaudal axis. $\boldsymbol{b}$, Right, Coronal view of neuron tjx31a. The cell was recognized as L-ITCc primarily from its large oval soma and long, thick aspiny secondary dendrites that ran parallel to the intermediate capsule. Note the three secondary dendritic branches extending medially into the AStria. c, Left, Lateral view of the reconstructed soma and dendrites of another in vivo recorded L-ITCC (tjx24a). c, Right, Coronal view of neuron tjx24a. Scale bars refer to the right panels only. Because of the skewed view of the left panels, scale bars are not provided. $\boldsymbol{d}$, Accumulation of mGlu1 $\alpha$ at the dendritic membrane of neuron tjx31a (z-stack projection). Scale bars: $\boldsymbol{b}, \boldsymbol{c}, 150 \mu \mathrm{m} ; \boldsymbol{d}, 5 \mu \mathrm{m}$. BA, Basal nucleus; CeA, central nucleus; ec, external capsule; ic, internal capsule; ITCd, dorsomedial intercalated cluster; ITCm, main ITC cluster; LA, lateral nucleus.

ing (Table 2). A $40 \times$ objective was used for counting $(3$ sections/rat for each experiment, $n=3$ animals), as described previously (Sreepathi and Ferraguti, 2012). The overall proportion of double-positive cells relative to the total number of mGlul $\alpha+$ cells was computed for each animal. Proportions were then averaged across animals.

Assessment of the projected area of the somata of labeled mGlu $1 \alpha$ cells located within or nearby the intermediate or external capsules and mGlu $1 \alpha$-labeled cells located within the BLA was performed on sections (two sections/rat for each experiment, $n=5$ animals) processed for immunocytochemistry according to the streptavidin-biotin-horseradish peroxidase (HRP) enzymatic complex (ABC Elite kit, Vector Laboratories), with diaminobenzidine (DAB) as a chromogen (Sreepathi and Ferraguti, 2012). Area measurements were performed manually using an Olympus BX51 microscope (with a $40 \times$ objective) and the Neurolucida software (MBF Bioscience).

Reconstructions of juxtacellularly labeled neurons tjx6b, tjx24a, and tjx31a were performed in three dimensions using an Olympus BX51 microscope (with a $63 \times$ oil 1.4 NA objective) and the Neurolucida software. Morphometric analyses were performed using the Neurolucida Explorer software (MBF Bioscience). Neuron tjx67a was reconstructed with a drawing tube.

Electron microscopy. Electron microscopy was used to validate light microscopic observations of putative synaptic connectivity. Sections used for electron microscopy were cryoprotected with $20 \%$ w/v sucrose in PB $0.1 \mathrm{M}$ and freeze-thawed twice over liquid nitrogen to enhance penetration of reagents. Neurobiotin-filled neurons were visualized us- ing the streptavidin-biotin-HRP enzymatic complex (Vector Laboratories), with nickel-intensified DAB as a chromogen. For immunolabeling of parvalbumin (PV) for electron microscopy, Neurobiotin was revealed first. After incubation with an anti-PV primary antibody and a HRPcoupled secondary antibody, sections were washed and reacted with nonintensified DAB. Thus, the juxtacellularly labeled neuron appeared strongly electron-opaque, whereas $\mathrm{PV}+$ structures appeared more lightly stained.

The innervation of juxtacellularly labeled L-ITCcs by mGlu8 + terminals was also verified. A tetramethylbenzidine (TMB)-based reaction was used to visualize mGlu8a receptors, because it increases the sensitivity of the staining compared with DAB labeling (Doig et al., 2010). Sections were preincubated for $20 \mathrm{~min}$ in a solution made of $0.05 \% \mathrm{w} / \mathrm{v}$ ammonium paratungstate, $0.004 \% \mathrm{w} / \mathrm{v} \mathrm{NH}_{4} \mathrm{Cl}, 0.2 \% \mathrm{w} / \mathrm{v}$ D-glucose, and $0.005 \%$ v/v TMB-free base (dissolved in ethanol, Sigma-Aldrich) in PB, $\mathrm{pH}$ 6.0. Subsequently, the sections were reincubated in the same solution, to which glucose oxidase was added. Progression of the reaction was monitored under a stereomicroscope. Sections were washed $5 \mathrm{~min}$ in PB $0.1 \mathrm{M}$, and the reaction product was stabilized and enhanced with a $\mathrm{CoCl}_{2}-\mathrm{DAB}$ solution. The Neurobiotin-labeled neuron was finally visualized with nickel-DAB. In this preparation, TMB appeared as a crystal, i.e., electron-dense elongated material.

To systematically study the innervation of mGlul $\alpha+$ L-ITCcs by group III mGlu receptors, we used triple-immunolabeling, with silverintensified immunogold reactions for detecting presynaptic mGlu7a and postsynaptic mGlul $\alpha$ receptors, and immunoperoxidase using DAB as 

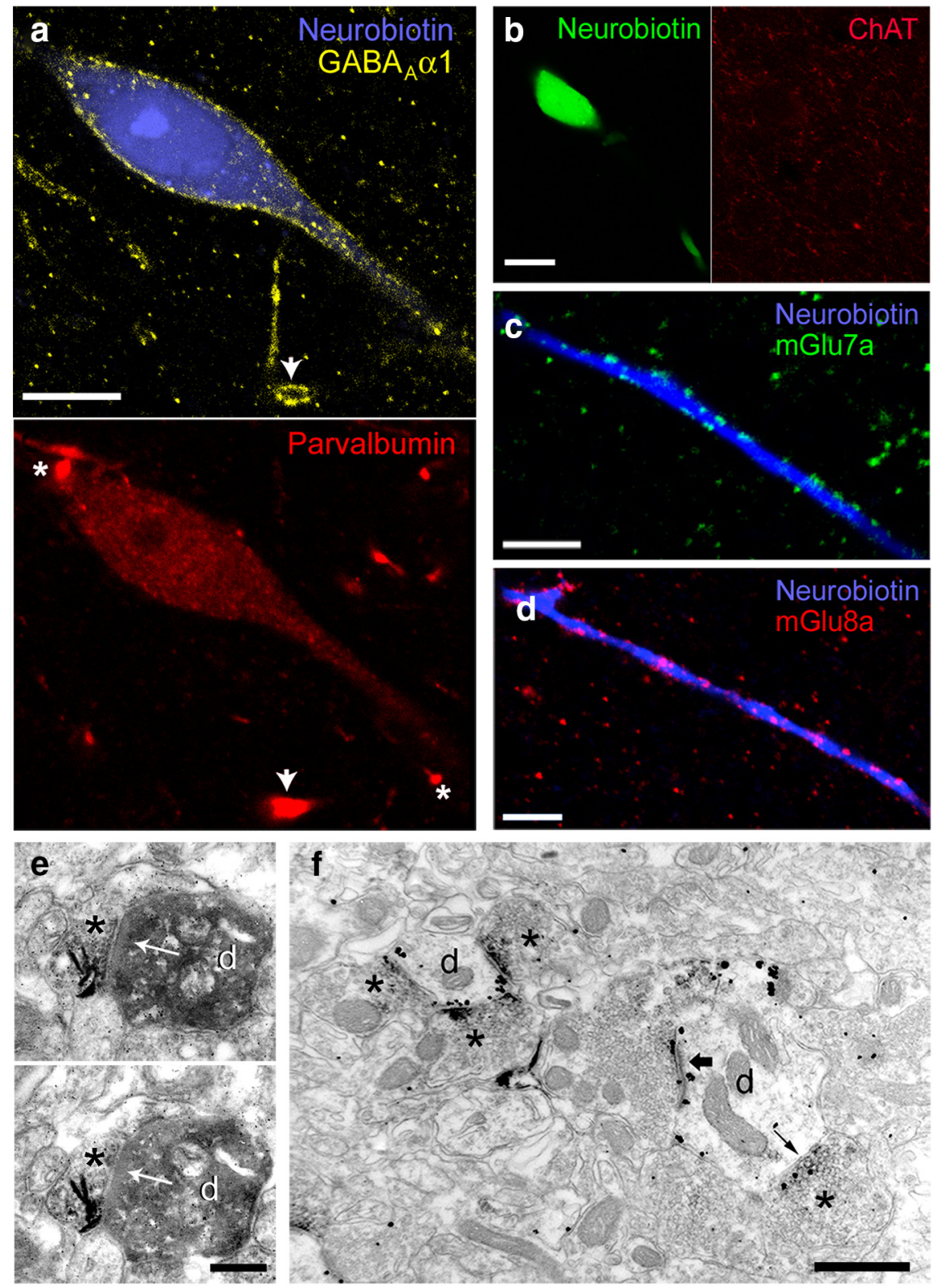

Figure 5. Neurochemical profile of recorded L-ITCcs. $\boldsymbol{a}$, Confocal micrographs showing strong expression of $\mathrm{GABA}_{A} \alpha 1$ (left) and moderate immunoreactivity for PV (right) in neuron tjx24a. Arrows denote nonfilled dendrites expressing comparatively higher levels of $\mathrm{PV}$ and $\mathrm{GABA}_{A} \alpha 1$; white asterisks indicate strongly PV-labeled nonfilled dendrites but devoid of $\mathrm{GABA}_{A} \alpha 1$ immunoreactivity. $\boldsymbol{b}, \mathrm{L}$-ITCcs are not cholinergic, as shown by the ChAT-negative biocytin-filled soma of tjx31a. $c$, Axon terminals containing mGlu7a receptors are apposed to the dendrites of L-ITCCs (tjx67a). $\boldsymbol{d}$, Decoration of L-ITCc dendrites (tjx24a) by boutons containing $m G l u 8 a$ receptors. $\boldsymbol{e}$, Electron micrograph of a synapse (arrow) between a mGlu8a + terminal $\left({ }^{*}\right)$ and a Neurobiotin-filled dendrite (d) of tjx24a (nickel-intensified DAB). $f$, Electron micrograph of a triple pre-embedding immunohistochemical reaction in which mGlu8a was visualized as a DAB-HRP reaction (dense precipitate *), whereas immunometal particles on postsynaptic dendritic ( $\boldsymbol{d})$ membranes revealed $m G l u 1 \alpha$, and immunometal particles on presynaptic membranes revealed $m G l u 7 a$. Clear presynaptic labeling for mGlu7a can be observed in boutons forming both symmetric (i.e., potentially GABAergic, small arrow) and asymmetric synapses (i.e., potentially glutamatergic, large arrow) with $\mathrm{mGlu} 1 \alpha+$ dendrites. Note that mGlu7 and $\mathrm{mGlu} 8$ receptors are often expressed in the same terminals. Scale bars: $\boldsymbol{a}, 10 \mu \mathrm{m} ; \boldsymbol{b}, 20 \mu \mathrm{m} ; \boldsymbol{c}, \boldsymbol{d}, 15 \mu \mathrm{m} ; \boldsymbol{e}, 250 \mathrm{~nm} ; \boldsymbol{f}, 500 \mathrm{~nm}$.

substrate for visualizing mGlu8a. Likewise, innervation of mGlu1 $\alpha+$ L-ITCcs by PHAL-containing thalamic axon terminals was revealed by double-immunolabeling with a silver intensified immunogold reaction for detecting postsynaptic mGlul $\alpha$, and an immunoperoxidase procedure for visualizing PHAL. These reactions were performed as described previously (Dobi et al., 2013).

After immunohistochemical processing, sections were postfixed with 1 or $2 \% \mathrm{OsO}_{4}$ (TAAB Laboratory Equipment; in PB $0.1 \mathrm{M}$ ), stained in $1 \%$ uranyl acetate (TAAB), dehydrated, embedded in epoxy resin (Durcu- pan; Fluka), and mounted on glass slides. After polymerization, regions-of-interest were selected and cut out under microscopic control, and re-embedded in resin. Serial ultrathin sections ( $\sim 70 \mathrm{~nm}$ thickness) were cut with an ultramicrotome (Ultracut S; Leica) and collected on Pioloform-coated copper slot grids. Analysis of the specimens was performed using a Philips CM 120 electron microscope. Sections were examined without further contrasting. Synapses were always followed in serial ultrathin sections.

\section{Results}

To gain insight into the structure and function of L-ITCcs, we combined the study of chemical markers of L-ITCc population with in vivo electrophysiological recordings and anatomical analysis of individual L-ITCcs.

First, neurochemical markers of L-ITCcs were identified. ITCc clusters in the rat amygdala, which are characterized by intense immunoreactivity for $\mu$-opioid receptors (Likhtik et al., 2008), were found to interdigitate with and be bordered by somata and dendrites of neurons expressing high levels of mGlul $\alpha$ receptors (Figs. $1 a, 2 a$ ), consistent with what we observed in the mouse brain (Busti et al., 2011; Dobi et al., 2013). These mGlu1 $\alpha+$ neurons had large $(>30 \mu \mathrm{m})$ mostly bipolar somata, and long, thick aspiny primary dendrites (Figs. $1 c, d, 2 a, b$ ), recapitulating a previous description of L-ITCcs based on Golgi impregnation (Millhouse, 1986). Because of their characteristic anatomical distribution (i.e., surrounding ITCcs and the BLA) and morphological features, these mGlu $1 \alpha+$ neurons were tentatively classified as L-ITCc. Although neurons expressing mGlul $\alpha$ were also observed in adjacent amygdala nuclei, e.g., BLA and medial nucleus, these displayed a distinct morphology from putative L-ITCcs, i.e., most of them had smaller multipolar somata and thinner dendrites. Furthermore, putative L-ITCcs clearly stood out from the neighboring structures for their very intense mGlu1 $\alpha$ labeling (Fig. 1a). To provide a quantitative characterization of these differences, we performed an analysis of the area of the soma of strongly labeled mGlul $\alpha+$ cells located within or nearby the intermediate or external capsules and mGlu1 $\alpha$-labeled cells located within the BLA ( $n=5$ rats). The area of the former group of cells $\left(299 \pm 10 \mu \mathrm{m}^{2}, n=41\right)$ was significantly larger $(p<0.0001, t$ test $)$ than the one of the latter cell group $\left(130 \pm 3 \mu \mathrm{m}^{2}, n=339\right.$; Fig. $\left.1 b\right)$. Interestingly, we observed a few outliers in the BLA showing a large somatic area and strong mGlu $1 \alpha$ labeling. These could represent L-ITCcs surrounding an ITC cluster located within the BLA (Fig. $2 a$; Busti et al., 2011). 
a
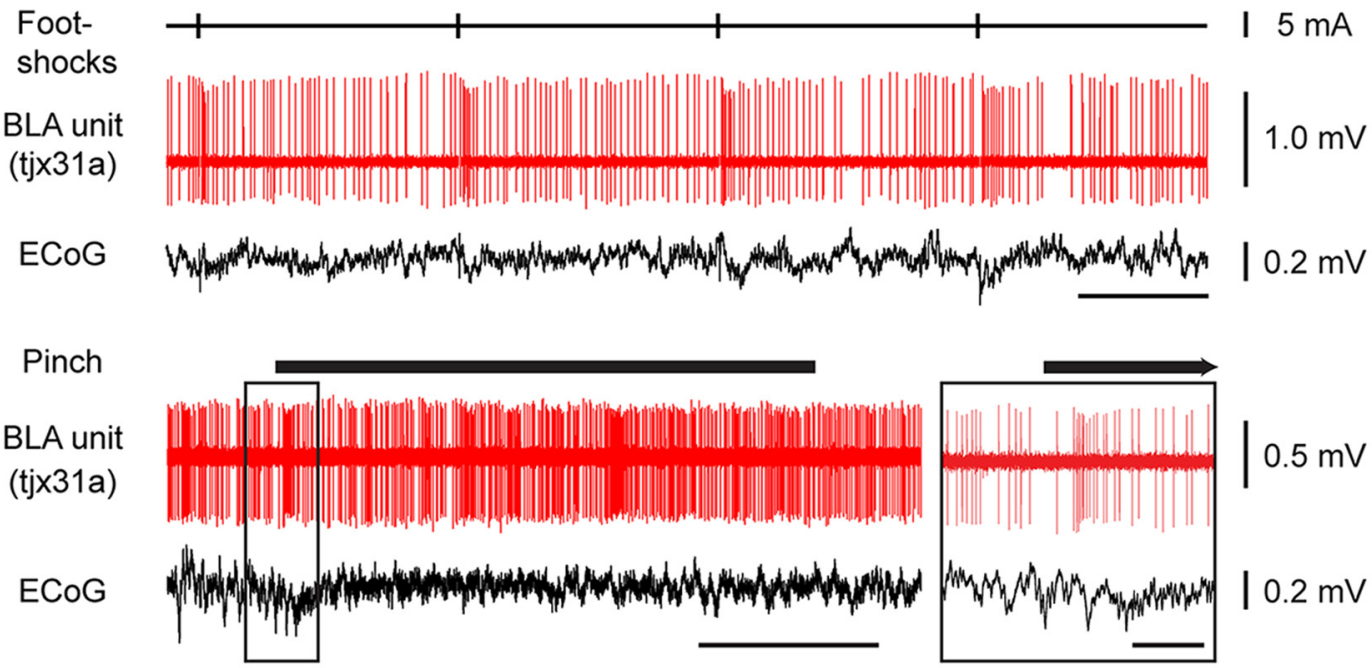

b Footshocks
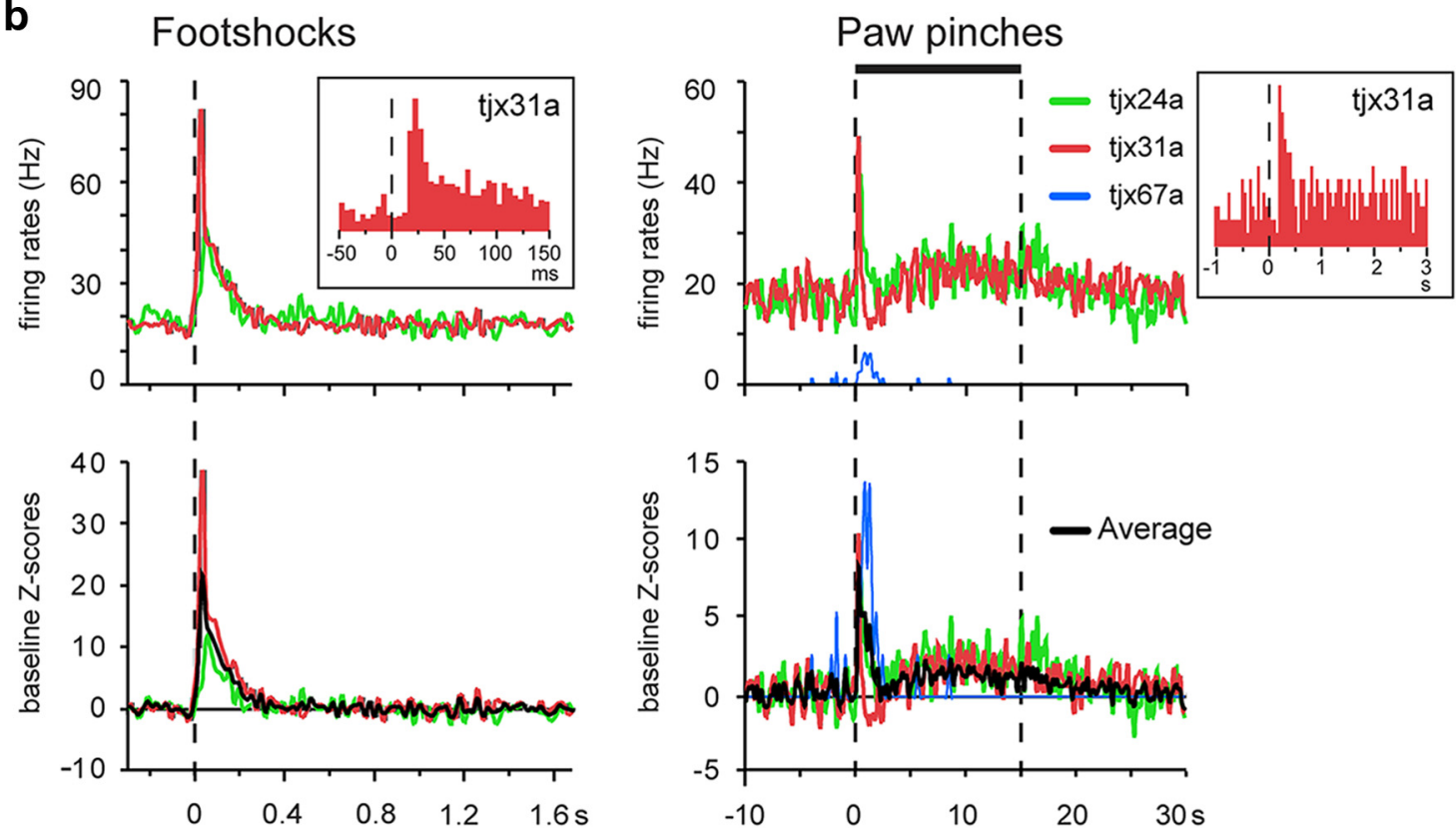

Figure 6. L-ITCcs are phasically excited by noxious stimuli. $\boldsymbol{a}$, Top, Representative firing response of a L-ITCc (tjx31a) to electrical footshocks (vertical bars) and (bottom) to a hindpaw pinch (top bar). Simultaneous ECoGs are also shown. Inset, The boxed area shows the traces immediately before and after the pinch at an expanded time scale. Note the strong and transient increase in firing rate shortly after noxious stimuli. $\boldsymbol{b}$, Peristimulus time histograms showing mean firing responses to electrical footshocks (bin size $20 \mathrm{~ms}$ ) and hindpaw pinches (bin size $200 \mathrm{~ms}$ ). Insets, Peristimulus firing rate of tjx31a at a shorter time scale (bins: left graph, $5 \mathrm{~ms}$; right graph, $50 \mathrm{~ms}$ ). Top, Raw firing frequencies; bottom, baseline z-score. Scale bars: $\boldsymbol{a}$, upper $1 \mathrm{~s}$, lower 5 s; inset, $500 \mathrm{~ms}$.

To further strengthen our operational definition of L-ITCcs, we extended our analysis to additional neurochemical markers. All mGlu $1 \alpha+$ L-ITCcs showed intense labeling for the GABA receptor subunit $\alpha 1\left(\mathrm{GABA}_{\mathrm{A}} \alpha 1\right)$ and $45.0 \pm 6.3 \%$ of them expressed $\mathrm{PV}$, although often at lower levels compared with other PV-labeled cells nearby (Fig. 3; Tables 1,2). We also observed that the mGlul $\alpha+$ L-ITCcs were immunonegative for additional markers commonly used to label neurons of the rat amygdala including somatostatin (SOM; Fig. 3d; Table 2).

From a series of juxtacellularly recorded-labeled putative GABAergic neurons $(n=53)$ obtained in urethane-anesthetized rats, four neurons could be identified post hoc as L-ITCcs. The relatively low success rate of L-ITCc recordings in such experi- ments is consistent with the scattered distribution and low numbers of putative L-ITCcs along the intermediate and external capsules observed in our previous set of experiments and in a previous report (Millhouse, 1986). Anatomical analysis of the recorded neurons revealed large somata (long axis range: $38-47$ $\mu \mathrm{m})$ and mainly aspiny dendrites, typical of L-ITCcs. Three of these neurons (tjx6b, tjx24a, tjx31a) had somata located close to the dorsomedial ITC cluster (Fig. 4a). For two of them (tjx24a and 31a), part of their dendrites extended into the amygdala/striatum transition area (AStria), whereas some dendrites of the third neuron (tjx6b) entered the BLA or the CeA. Neurolucida reconstruction of these neurons revealed that their dendritic tree formed a ventrodorsal angle in the 
a

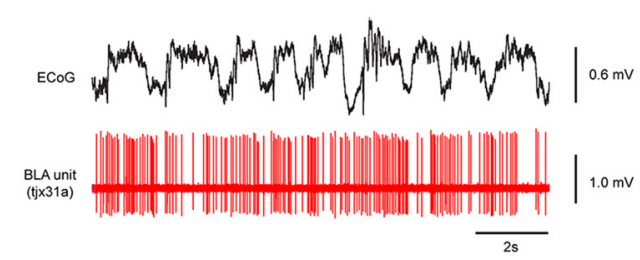

b

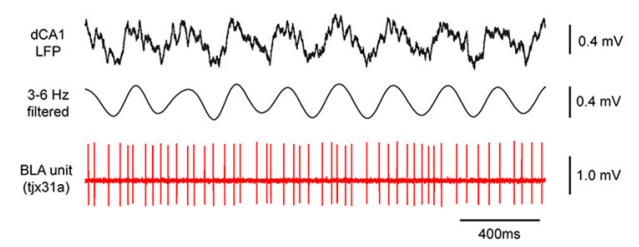

C
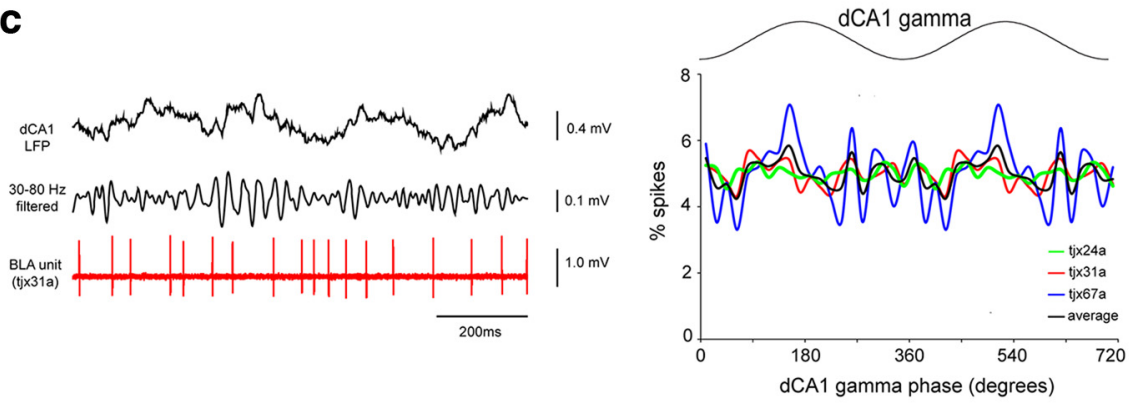

d
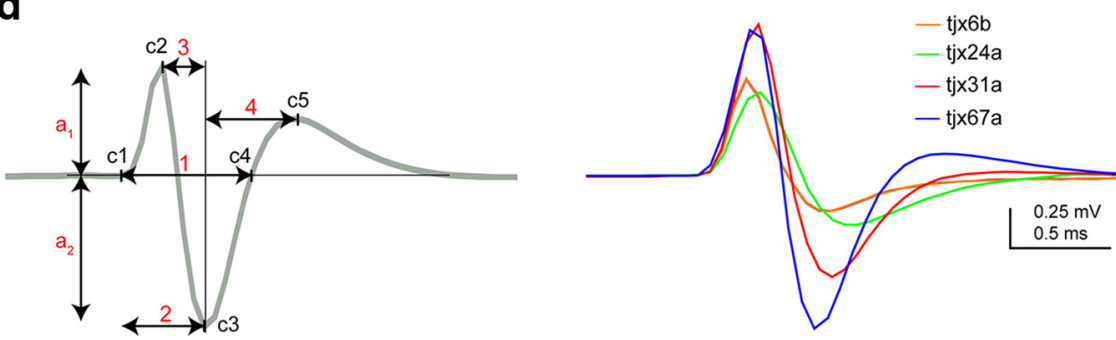

Figure 7. Firing of L-ITCcs in relation to network oscillations and their extracellular spike waveforms. $\boldsymbol{a}$, Firing relationships of L-ITCcs with ECOG slow-wave activity (1-2 Hz; SW). Left, Original traces; note the prominent slow oscillations in the ECoG signal. Right, Phase plots of the distribution of all spikes across ECOG SWA cycles for each neuron and on average. Slow oscillations cycle has been duplicated for clarity. $\boldsymbol{b}, \boldsymbol{c}$, Firing relationships of L-ITCcs with dCA1 theta (b) or gamma (c) oscillations. Left, Original traces; spiking of L-ITCCS was not significantly modulated by dCA1 theta or gamma oscillations. Right, Phase plots, showing the distribution of spikes across $\mathrm{dCA} 1$ theta or gamma oscillation cycles. Cycles have been duplicated for graphical representation. $\boldsymbol{d}$, Extracellular spike waveform analysis. Left, Schematic of the parameters measured for each cell. Total width (c1- c4), baseline to trough $(\mathrm{c} 1-\mathrm{c} 3)$, first peak to trough $(\mathrm{c} 2-\mathrm{c} 3)$, trough to second peak duration (c3-c5); a1/a2: first peak/trough amplitude ratio. Right, Mean spike waveform of each neuron normalized to peak amplitude. The quantification of these data are shown in the Table 3 .

rostrocaudal axis (Fig. $4 b, c$ ). The soma of the fourth neuron (tjx67a) was located ventrolaterally to the BLA and its thick dendrites followed the external capsule, with some branches extending into the BLA (Fig. $4 a$ ).

All recorded L-ITCcs tested were strongly immunoreactive for mGlu1 $\alpha$ including the laterally located one $(n=3 / 3$; Fig. $4 d)$. These neurons also strongly expressed the $\mathrm{GABA}_{\mathrm{A}} \alpha 1$ receptor subunit ( $n=2 / 2$; tjx24a and tjx31a tested), and moderate levels of PV ( $n=2 / 2$; tjx24a and tjx31a tested), compared with nearby
PV+ interneurons in the BLA (Fig. 5a). Furthermore, the recorded cells were immunonegative for choline acetyltransferase (ChAT; $n=3 / 3$; tjx24a, tjx31a and tjx67a tested; Fig. $5 b)$, NK1 receptor $(n=$ $2 / 2 ;$ tjx $24 \mathrm{a}$ and tjx31a tested, data not shown $)$ and SOM $(n=1 / 1$; tjx31a tested, data not shown). Our data, therefore, do not support the view that L-ITCcs are cholinergic neurons, as previously suggested in the amygdala of the monkey (McDonald and Augustine, 1993) and cat (Paré and Smith, 1993). The projected area of the soma of in vivo recorded L-ITCcs was also analyzed and found to be similar ( $\left.314 \pm 37 \mu \mathrm{m}^{2}, n=4\right)$ to that measured in nonrecorded rats (Fig. 1b), indicating that large somata is a distinctive feature of L-ITCcs.

We previously showed that mGlu1 $\alpha$ intensely immunopositive cells around ITC clusters in the mouse amygdala are densely innervated by axon terminals expressing group III mGlu receptors, namely mGlu7a and/or mGlu8a receptors (Dobi et al., 2013). The L-ITCcs recorded in vivo in the rat followed this general pattern. Boutons expressing mGlu8a or mGlu7a receptors densely innervated dendrites of the Neurobiotin-filled L-ITCcs, $(n=3 / 3$; tjx24a, tjx31a, and tjx67a tested; Fig. $5 c, d)$. This result was also obtained with light microscopy from nonrecorded rat preparations (data not shown). We verified with electron microscopy in the in vivolabeled neurons that mGlu8a + boutons formed synapses with L-ITCc dendrites (Fig. 5e). A complex pattern of coexpression between mGlu7a and mGlu8a receptors was revealed by triple pre-embedding immuneelectron microscopy performed in sections of nonrecorded neurons. A qualitative analysis of this reaction showed coexistence between mGlu7a and mGlu8a receptors in axon terminals forming synapses with mGlu1 $\alpha$-labeled dendrites (Fig. 5f), although others terminals showed labeling for only one of these receptors.

Together, these data indicate that L-ITCcs are a distinct cell type, that can be defined based on morphological criteria and a combination of neurochemical markers. Following this, four in vivo recorded cells could be reliably classified as L-ITCcs. Thus, the recorded L-ITCcs are likely to constitute a representative sample of the L-ITCc population in the rat amygdala.

\section{In vivo firing activity: L-ITCcs are robustly activated by noxious stimuli}

Next, we studied the firing of the identified L-ITCcs in anesthetized rats. We observed that the dorsomedially located L-ITCcs fired at high-frequencies during cortical slow-wave activity and 


\begin{tabular}{|c|c|c|c|c|c|c|}
\hline Parameters/recorded neurons & tjx6b & tjx24a & tjx31a & tjx67 & Average & SEM \\
\hline \multicolumn{7}{|l|}{ Spike duration parameters (ms) } \\
\hline No. of spikes & 150 & 150 & 150 & 150 & - & - \\
\hline Total width (c1-c4) & - & 1.77 & 1.28 & 0.93 & 1.33 & 0.42 \\
\hline Baseline-trough ( $c 1-c 3)$ & 0.64 & 0.76 & 0.67 & 0.56 & 0.66 & 0.08 \\
\hline 1st peak-trough (c2-c3) & 0.41 & 0.46 & 0.37 & 0.30 & 0.39 & 0.07 \\
\hline Trough-2nd peak (c3-c5) & - & 1.68 & 0.87 & 0.61 & 1.05 & 0.56 \\
\hline \multicolumn{7}{|l|}{ Spike amplitude parameters } \\
\hline 1st peak/through (a1/a2) & 3.05 & 1.27 & 2.28 & 1.19 & 1.95 & 0.89 \\
\hline Amplitude $(\mathrm{a} 1+\mathrm{a} 2, \mathrm{mV})$ & 0.85 & 0.85 & 1.56 & 2.02 & 1.32 & 0.57 \\
\hline \multicolumn{7}{|c|}{ Firing during $\mathrm{d} C \mathrm{~A} 1$ theta oscillations } \\
\hline Rate $(\mathrm{Hz})$ & - & 17.7 & 17.4 & 0.4 & 11.8 & 5.7 \\
\hline $\mathrm{CV}$ & - & 0.63 & 0.59 & 1.51 & 0.91 & 0.30 \\
\hline$p$ (Rayleigh) & - & 0.52 & 0.79 & 0.55 & - & - \\
\hline \multicolumn{7}{|c|}{ Firing during $\mathrm{d} C \mathrm{C} 1$ gamma oscillations } \\
\hline Rate $(\mathrm{Hz})$ & - & 18.6 & 15.6 & 0.4 & 11.5 & 5.6 \\
\hline $\mathrm{CV}$ & - & 0.38 & 0.15 & 1.33 & 0.62 & 0.36 \\
\hline$p$ (Rayleigh) & - & 0.84 & 0.65 & 0.41 & - & - \\
\hline \multicolumn{7}{|c|}{ Firing during $\mathrm{ECOG}$ slow-wave oscillations } \\
\hline Rate (Hz) & 8.6 & 22.9 & 12.7 & - & 14.7 & 4.3 \\
\hline $\mathrm{CV}$ & 1.10 & 0.90 & 0.80 & - & 0.93 & 0.09 \\
\hline$p$ (Rayleigh) & $<0.001$ & 0.02 & 0.01 & - & - & - \\
\hline
\end{tabular}

activated states, whereas the lateral cell fired sparsely and more irregularly (Table 3). Strikingly, the firing of L-ITCcs was strongly modulated by noxious stimuli (Fig. 6), such as a footshock that resembles the commonly used unconditioned stimulus delivered in fear conditioning and potently activates nociceptive circuits under urethane anesthesia (Coizet et al., 2006). Dorsomedially located L-ITCcs responded to hindpaw pinches with a fast excitation (Fig. 6; tjx24a and 31a: peak and latency: $200 \mathrm{~ms}$; tjx24a: $+148 \%$, tjx31a: $+180 \%)$. This initial firing increase adapted rapidly, but it remained sustained $(\sim 30-$ $40 \%$ increase of firing rate) during the stimulation. The laterally located L-ITCcs (tjx67a) fired sparsely at baseline, but it was also transiently excited at the onset of hindpaw pinches (Fig. $6 b$; increase from $<0.5$ to $6.25 \mathrm{~Hz}$, latency: $200 \mathrm{~ms}$, peak $800 \mathrm{~ms}$ ). Likewise, two dorsomedial L-ITCcs were sharply excited by electrical footshocks (Fig. 6; tjx24a: $+140 \%$, latency $<20$ ms, peak 40 ms; tjx31a: $+370 \%$, latency $<20 \mathrm{~ms}$, peak $20 \mathrm{~ms}$ ). Overall, the firing rates of L-ITCcs strongly and transiently increased with short latencies after application of footshocks or hindpaw pinches (Fig. $6 b$; means: electrical footshocks: baseline $z$-score $=$ 13.3, latency $=15 \mathrm{~ms}, n=2$; hindpaw pinches: baseline $z$-score $=$ 8.0 , latency $=200 \mathrm{~ms}, n=3$ ). Noteworthy, the longer latency of the response observed after pinches was due to technical reasons: the device used for paw pinch requires time to close on the paw and to apply sufficient pressure to reach nociceptive threshold ( $\sim 180 \mathrm{~ms}$; see Materials and Methods). In contrast, electrical footshocks are delivered nearly instantaneously. When this delay was taken into account, the response latencies between tail pinch and electrical footshocks were similar (20 ms range).

Oscillatory rhythms are important elements of neuronal ensemble activities, play a role in fear memory and some cell types in the amygdala fire in phase with local or distant oscillations (Paré and Gaudreau, 1996; Bienvenu et al., 2012; Courtin et al., 2014). We assessed the firing modulation of L-ITCcs associated with various oscillatory patterns. Our results showed that L-ITCcs fired independently from cortical slow-wave activity $(n=2 / 3$; Fig. $7 a$ ) or from CA1 hippocampal theta or gamma oscillations $(\mathrm{n}=3 / 3$; Fig. $7 b, c)$, suggesting that L-ITCcs are not engaged in coordinating network oscillations between these brain areas. Interestingly, the duration of spikes recorded from L-ITCcs was on average $1.33 \pm 0.42 \mathrm{~ms}$ (Fig. $7 d$; Table 3 ), comparable to the spike duration we reported in GABAergic neurons of the BLA recorded under similar conditions (Bienvenu et al., 2012). Together, our data constitute the first electrophysiological study of L-ITCcs and reveal a functional profile characterized by a prompt and vigorous firing increase in response to noxious stimuli.

\section{Monosynaptic innervation of L-ITCcs by the posterior intralaminar thalamus}

Posterior intralaminar thalamic nuclei (PIN) are thought to carry nociceptive information to the amygdala and participate in synaptic plasticity underlying fear memory formation (Linke et al., 2000). We postulated that L-ITCcs receive synaptic inputs from this thalamic region, accounting for L-ITCc responses to noxious stimuli. Therefore, we next tested the innervation of dorsomedial mGlul $\alpha+$ L-ITCcs following the injection of the anterograde tracer PHA-L in the PIN. As the injection site was correctly placed and restricted to the PIN in 3 of 7 rats (Fig. $8 a, b$ ), tract tracing was further analyzed only in sections from these animals. Intense axonal labeling could be observed in the lateral amygdala and AStria (Fig. 8c), as previously described (Linke et al., 2000). Moreover, using immunofluorescence double-labeling, we found that thalamic axons frequently made close appositions (i.e., putative synapses) with mGlul $\alpha+$ dendrites of L-ITCcs (Fig. 8d,e). Electron microscopic analysis of a subset of these axons confirmed that PHA-L-filled axon terminals of intralaminar thalamic neurons formed asymmetric synaptic contacts with mGlu $1 \alpha+$ profiles in the ITC regions (Fig. $8 f$ ). Thus, noxious stimulus-driven excitation of L-ITCcs with the soma located close to the intermediate capsule might result from direct thalamic relay, which is consistent with the short latency responses of L-ITCcs to noxious stimuli.

\section{L-ITCcs provide local and long-range GABAergic innervation of interneurons}

To evaluate the potential impact of L-ITCc activity on brain network activity, particularly during noxious stimulation it is critical to identify the neurotransmitters they release, as well as their synaptic targets. We found that the axon terminals of recorded neurons ( $n=2 / 2$ tested) expressed the vesicular GABA transporter (VGAT; Fig. $9 b ; n=2 / 2$, tjx24a and tjx31a tested), and exclusively made symmetric synaptic contacts $(n=$ 29/29 randomly selected synapses; Fig. 9c). Together, these results provide compelling evidence that L-ITCcs are GABAergic neurons.

Subsequently, we characterized the axonal arborization and the postsynaptic targets of the recorded L-ITCcs. This information is required not only to further characterize L-ITCcs as a neuron type, but also to elucidate the substrates by which they could influence neuronal network activities. We studied in detail the axonal projections of two dorsomedial L-ITCcs that could be reconstructed (Fig. 9a,d; Table 4). The main axons of these L-ITCcs emitted several branches, some of which contributed to the numerous terminal collaterals in the BLA $(\sim 70-85 \%$ of total axonal length, $\sim 85-95 \%$ of varicosities; Table 4 ), whereas other myelinated branches (Fig. 9c) projected rostrally or caudally over long distances, with a total anteroposterior extent of $\sim 7 \mathrm{~mm}$. Long-range projections ended and innervated rostrally the endopiriform nucleus and caudally the perirhinal and lateral entorhinal cortices. In the BLA, PV+ interneuron dendrites or somata appeared targeted by L-ITCC 

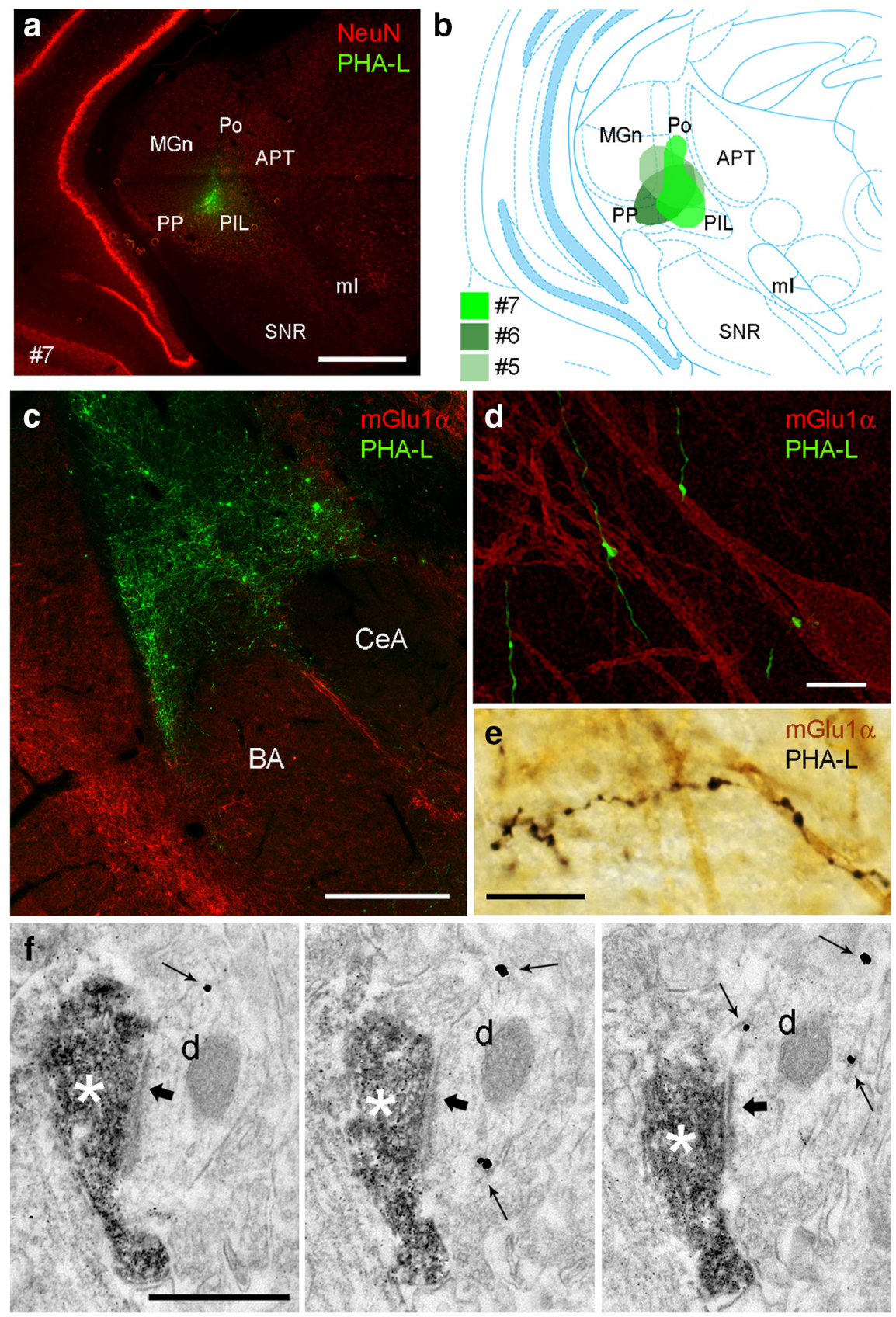

Figure 8. The posterior intralaminar thalamus innervates L-ITCcs. $\boldsymbol{a}$, Micrograph showing the PHA-L injection site in the posterior paralaminar thalamic nuclei for rat no. 7. Neuronal nuclear antigen (NeuN) immunoreactivity reveals neuronal cell bodies. $\boldsymbol{b}$, Line drawing of a rat brain coronal section (Paxinos and Watson, 2007) showing an overview of the extent of PHA-Llabeled cells in three animals, selected from a larger series of injections $(n=7)$. In these cases, the injection site was mostly confined to the target, i.e., posterior intralaminar thalamus, comprising PIL, PoT, and Po. Each injection is illustrated with a different green shading pattern. Little variability in the pattern of axonal labeling was observed among these three injections. $c$, PHA-L anterograde tracing of projections from the posterior intralaminar thalamus (green) to mGlu1 $\alpha+L-I T C c$ (red). $\boldsymbol{d}, \boldsymbol{e}$ Thalamic axons made frequent appositions with mGlu1 $\alpha+$ L-ITCC dendrites. $f$, Synapse between a PHA-L-filled axon terminal (DAB staining) and a mGlu $1 \alpha+$ (immunometal particles; arrows) L-ITCc dendrite. Scale bars: $\boldsymbol{a}, 1 \mathrm{~mm} ; \boldsymbol{c}, 500 \mu \mathrm{m} ; \boldsymbol{d}, \boldsymbol{e}, 10 \mu \mathrm{m} ; \boldsymbol{f}$, $500 \mathrm{~nm}$. APT, Anterior pretectal nucleus; BA, basal nucleus; CeA, central nucleus; $d$, dendrite; $M G n$, medial geniculate nucleus; $m \mathrm{ml}$ medial lemniscus; PIL, posterior intralaminar thalamic nucleus; P0, posterior thalamic nuclear group; PP, peripeduncular nucleus; SNR, substantia nigra, reticular part.

axon terminals. Targeted PV + interneurons were putative basket cells of the BLA, as they strongly coexpressed calbindin (CB; Bienvenu et al., 2012; Fig. 10a). Electron microscopy confirmed that the large majority of axon terminals of recorded L-ITCcs that were examined in the BLA formed sym- metric synapses with $\mathrm{PV}+$ interneurons $(n=17 / 23$; Fig. $10 b, c)$. Likewise, in perirhinal and lateral entorhinal cortices, L-ITCc-filled axons formed symmetrical synapses with putative interneurons, recognized by the presence of asymmetric synapses on their dendritic shafts (Figs. $9 c$; $10 e$ ).

Our analysis suggests that dorsomedial L-ITCcs project through long-range axonal branches to the BLA and associative cortices where they provide GABAergic innervation to local interneurons. This axonal pattern is in marked contrast with that of small-spiny ITCcs (Amir et al., 2011; Busti et al., 2011) suggesting a novel and specialized functional role of L-ITCcs in disinhibiting principal neurons.

\section{Discussion}

The present work defines for the first time L-ITCcs of amygdala based on a broad operational definition of their structural and neurochemical features, axonal patterns, and firing properties. Our data suggest that L-ITCcs respond to salient sensory stimuli, target interneurons, and are likely to coordinate the activity of principal neurons of the BLA and associative cortices in relation to unconditioned fear responses.

The L-ITCcs were first described in a Golgi-impregnation study of the rat amygdala (Millhouse, 1986). Our recorded L-ITCcs with their soma located within the intermediate capsule matched in all aspects the previous description of L-ITCcs obtained with the Golgi method (Millhouse, 1986). Their large somata gave rise to bipolar dendritic arrangements that were mostly confined to the intermediate capsule, although some branches could be seen entering the BLA, AStria, or CeA. On the other hand, the soma of one neuron (tjx67a) was located in the external capsule and its dendritic tree was multipolar with some dendrites following the external capsule and others branching into the BLA. Although this pattern was not reported earlier for L-ITCcs, all other analyzed features of this neuron resembled those observed for the other L-ITCcs, including similar functional responses. This indicates that it most likely belongs to the same neuron class. However, further work to solve this issue is warranted.

Our immunohistochemical data demonstrate that L-ITCcs can be recognized by their particularly intense expression of the $m$ Glu $1 \alpha$ receptor and $\mathrm{GABA}_{\mathrm{A}} \alpha 1$ subunit and moderate levels of PV, as well as by innervation by inputs expressing group III mGlu receptors. Interestingly, such a combination of molecular markers has been previously reported for large GABAergic palli- 


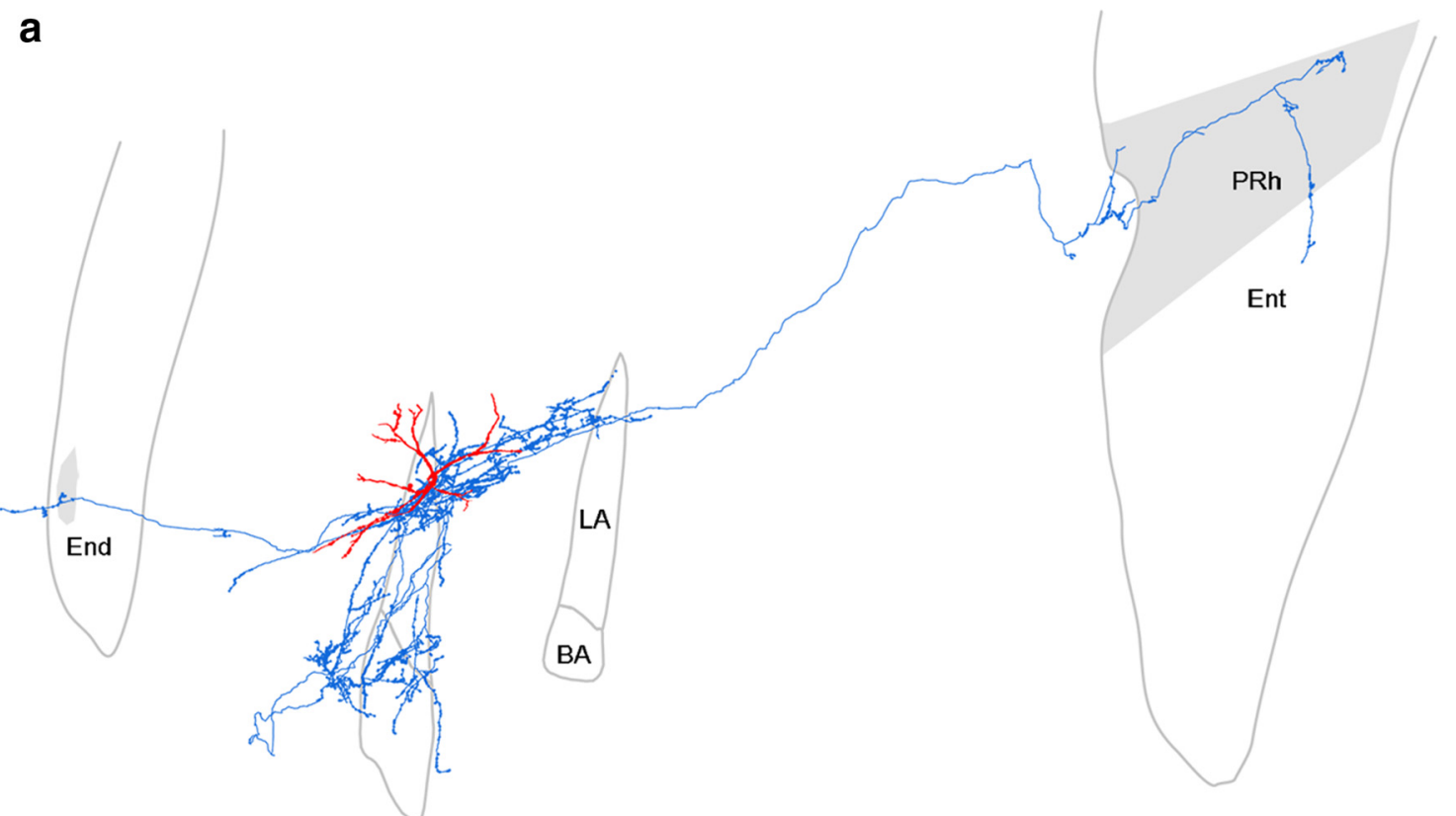

b
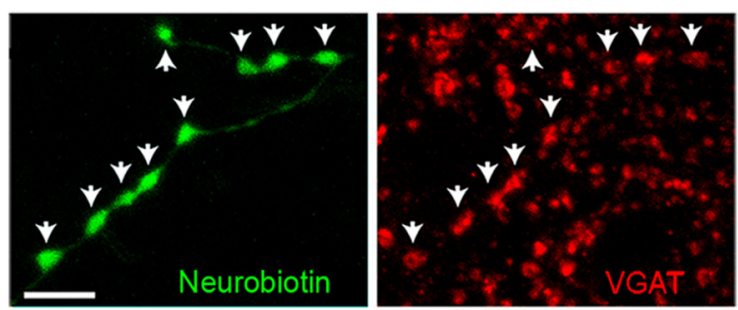

\section{C}

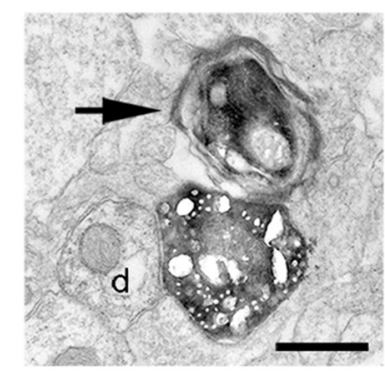

d

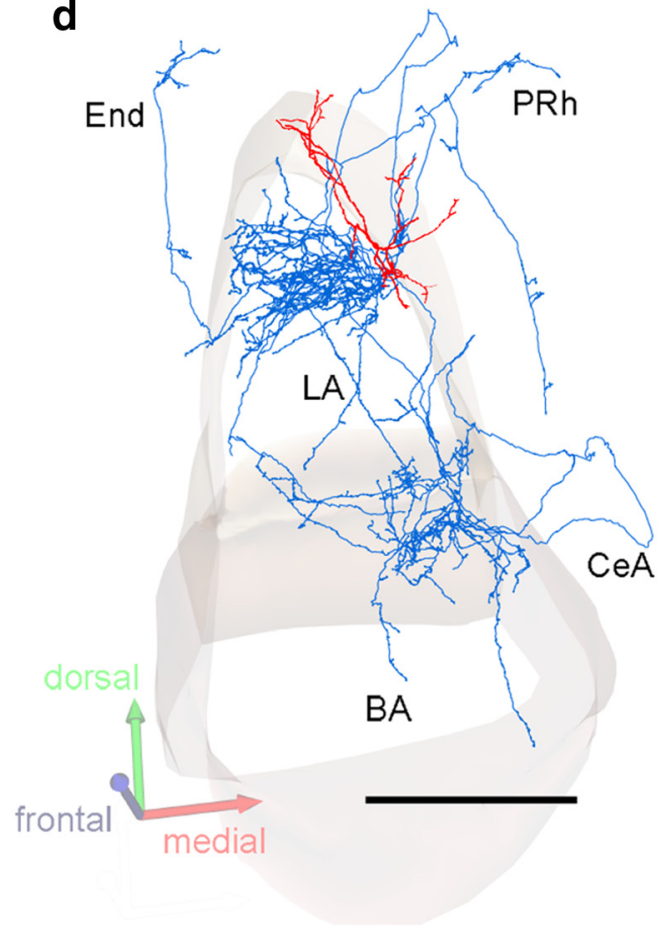

Figure 9. L-ITCcs are long-range GABAergic projecting neurons. $\boldsymbol{a}, \boldsymbol{d}$, Lateral and frontal views of a reconstructed L-ITC $\mathbf{c}$ with soma and dendrites (red) in the intermediate capsule. The axon (blue) innervates predominantly the BLA and projects rostrally to the endopiriform (End) nucleus and caudally to the perirhinal cortex (PRh). Because of the skewed view of the panel shown in $\boldsymbol{a}$, scale bars are not provided. $\boldsymbol{b}$, L-ITC axon terminals are GABAergic (VGAT+ axonal varicosities, arrows). $\boldsymbol{c}$, Electron micrographs of a myelinated axonal branch (arrow) and of a symmetric (type II) synapse between a filled bouton and a dendrite (d) in the LA. All data shown here were obtained from neuron tjx31a. Scale bars: $\boldsymbol{b}, 5 \mu \mathrm{m} ; \boldsymbol{c}, 500 \mathrm{~nm} ; \boldsymbol{d}, 500 \mu \mathrm{m}$. BA, Basal nucleus; CeA, central nucleus; Ent, entorhinal cortex; LA, lateral nucleus.

dal neurons (Fritschy et al., 1992; Ferraguti et al., 2005; Gross et al., 2011) suggestive of a common developmental origin (i.e., the medial ganglionic eminence).

Our use of extracellular single-neuron recordings and juxtacellular labeling allowed for an unprecedented characterization of L-ITCc output connectivity, as well as firing activity in vivo, which cannot be readily achieved by other less challenging approaches. However, the use of the juxtacellular recording/labeling approach comes with the limitation of a low cell-yield, which when combined with the low abundance and sparse distribution of L-ITCcs led us to identify four L-ITCcs of tens of neurons recorded in the amygdala (our in vivo recordings had the aim to detect highly active, i.e., putative GABAergic neurons). Notwithstanding, a similar sample size is common for GABAergic neurons recorded with the same approach not only in the amygdala but also in other intensively studied brain areas, such as the hippocampus or the neocortex (Klausberger et al., 2003; Fuentealba et al., 2008; Isomura et al., 2009; Bienvenu et al., 2012). Importantly, morphological and neurochemical aspects of the recorded neurons fully matched those of L-ITCcs defined anatomically at the 
Table 4. Quantification of the axonal length and number of varicosities of reconstructed L-ITCcs in different brain areas

\begin{tabular}{|c|c|c|c|c|}
\hline \multirow[b]{2}{*}{ Area } & \multicolumn{2}{|l|}{ tjx31a } & \multicolumn{2}{|l|}{ tjx24a } \\
\hline & $\begin{array}{l}\text { Axonal } \\
\text { length (mm) }\end{array}$ & $\begin{array}{l}\text { No. of } \\
\text { varicosities }\end{array}$ & $\begin{array}{l}\text { Axonal } \\
\text { length (mm) }\end{array}$ & $\begin{array}{l}\text { No. of } \\
\text { varicosities }\end{array}$ \\
\hline $\mathrm{LA}$ & $31,714(47.0 \%)$ & $2159(63.6 \%)$ & $72,096(67.2 \%)$ & $2.791(78.4 \%)$ \\
\hline$B A$ & $14,278(21.1 \%)$ & $753(22.2 \%)$ & $22,252(20.7 \%)$ & $527(14.8 \%)$ \\
\hline $\mathrm{ITCd}$ & $1445(2.1 \%)$ & $37(1.1 \%)$ & $2288(2.1 \%)$ & $124(3.5 \%)$ \\
\hline $\mathrm{ITCm}$ & 0 & 0 & $192(0.2 \%)$ & $4(0.1 \%)$ \\
\hline Interm capsule & 757 (1.1\%) & $8(0.2 \%)$ & $1687(1.6 \%)$ & $10(0.3 \%)$ \\
\hline External capsule & $4778(7.1 \%)$ & $46(1.3 \%)$ & $2568(2.4 \%)$ & $33(0.9 \%)$ \\
\hline CeL & $2262(3.4 \%)$ & $12(0.4 \%)$ & $860(0.8 \%)$ & $2(0.1 \%)$ \\
\hline CeM & $96(0.1 \%)$ & 0 & $479(0.4 \%)$ & $3(0.1 \%)$ \\
\hline BNST & 0 & 0 & $312(0.3 \%)$ & $9(0.2 \%)$ \\
\hline IPAC/striatum & $178(0.3 \%)$ & $9(0.3 \%)$ & $512(0.5 \%)$ & $23(0.6 \%)$ \\
\hline Perirhinal cortex & $4471(6.6 \%)$ & $139(4.1 \%)$ & 0 & 0 \\
\hline Entorhinal cortex & $401(0.6 \%)$ & $25(0.7 \%)$ & $393(0.4 \%)$ & $7(0.2 \%)$ \\
\hline Endopiriform cortex & $7069(10.5 \%)$ & $209(6.1 \%)$ & $3622(3.4 \%)$ & $28(0.8 \%)$ \\
\hline Total & 67,449 & 3397 & 107,261 & 3561 \\
\hline
\end{tabular}

Cells tjx31a and tjx24a were traced and analyzed with the Neurolucida software. BA, Basal nucleus; BNST, bed nucleus of stria terminalis; CeA, central nucleus; CeL, central nucleus lateral part; $C e M$, central nucleus medial part; IPAC, posterior limb of the anterior commissure; ITCd, dorsomedial intercalated cluster; ITCm, main ITC cluster; LA, lateral nucleus.
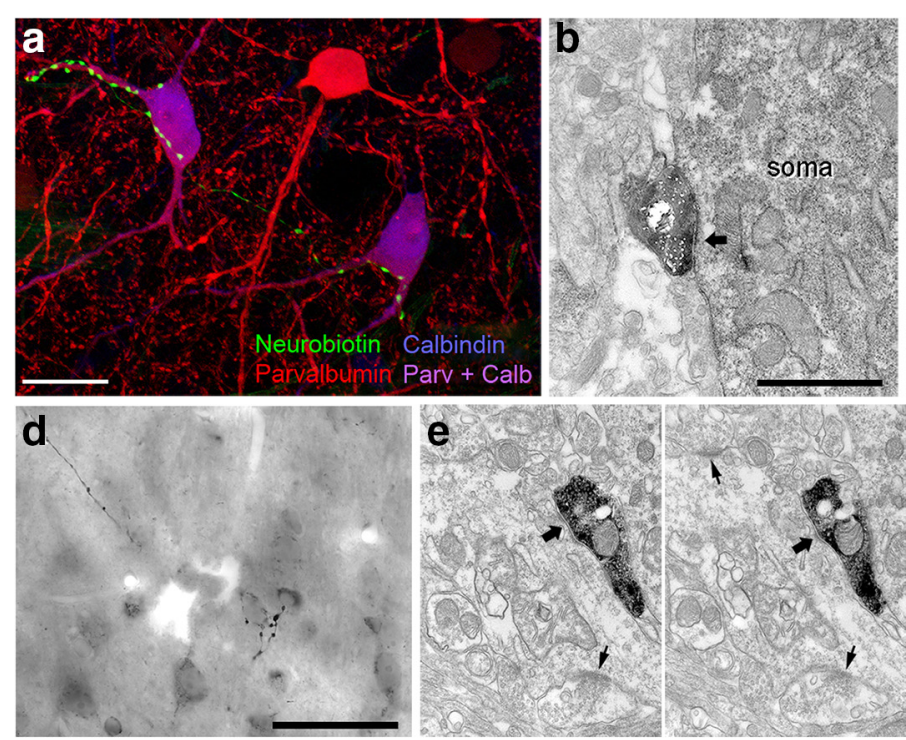

Figure 10. L-ITCCs innervate interneurons in the BLA and associative cortices. $\boldsymbol{a}$, Axon varicosities making close appositions with proximal dendrites and somata of putative basket cells in the BLA coexpressing CB and PV. $\boldsymbol{b}, \boldsymbol{c}$, Axon terminals of a L-ITCC forming symmetric synapses with a soma $(\boldsymbol{b})$ and a dendritic shaft $(\boldsymbol{c})$ of PV + interneurons in BLA. Note in $\boldsymbol{c}$ the presence of an asymmetric, (type I) synapse on the same dendritic shaft. $\boldsymbol{d}$, Composite micrograph of different focal depths of a L-ITCc axon in the perirhinal cortex (PRh). Axon terminals appeared apposed to neurons of small size containing strong levels of endogenous biotin (i.e., putative interneurons). $e$, Serial ultrathin sections of a symmetric synapse (thick arrow) in the PRh between an axon terminal of a L-ITC and a dendrite of a putative interneuron. Note the asymmetric shaft synapses (thin arrows) made on the same dendrite which indicates the target cell as an interneuron (Megías et al., 2001). All data shown were obtained from neuron tjx31a. Scale bars: $\boldsymbol{a}, 20 \mu \mathrm{m} ; \boldsymbol{b}, 1 \mu \mathrm{m} ; \boldsymbol{c}, 500 \mathrm{~nm} ; \boldsymbol{d}, 50 \mu \mathrm{m} ; \boldsymbol{e}, 1 \mu \mathrm{m}$. Calb, Calbindin; Parv, palvalbumin.

population level. Thus, the recorded neurons are likely representative of the overall population.

Basal firing rates of L-ITCcs were fast $(\sim 18 \mathrm{~Hz})$, consistent with a previous report of putative ITC neurons, potentially L-ITCcs, recorded in head-restrained cats (Collins and Paré, 1999), but in contrast with small-spiny ITCcs which fire at lower rates in similarly urethane-anesthetized rats (Amir et al., 2011). The average spike durations of L-ITCcs were similar to those observed in other GABAergic neuron types of the BLA, but shorter than those of BLA principal cells (Bienvenu et al., 2012) and small-spiny ITCcs (Amir et al., 2011) recorded under similar experimental conditions.
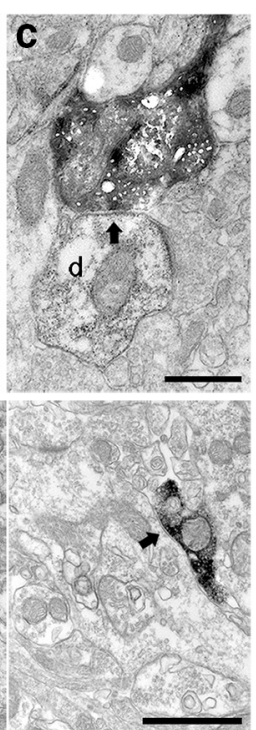

A prominent functional feature of recorded L-ITCcs was their large, transient, and prompt response to noxious stimuli. Indeed L-ITCcs increased their firing rate in response to footshocks with $<20 \mathrm{~ms}$ latency and $<40 \mathrm{~ms}$ peak. In comparison, axoaxonic interneurons of the BLA, which also increase their firing upon (isplay responses with $\sim 50 \mathrm{~ms}$ latency and $\sim 200 \mathrm{~ms}$ (Bienve responses suggest that tion. In keeping with this, we found that axons of posterior ralaminar thalamic neurons make synapses with mGlu $1 \alpha$ -

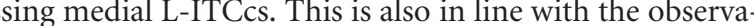
capsular part of the lateral nucleus of amygdala (Linke et al., 2000). The sharp firing increase in L-ITCcs evoked by nociceptive stimuli was quite brief, even during prolonged stimuli ( $\sim 200 \mathrm{~ms}$ tion vs $600 \mathrm{~ms}$ for axoaxonic BLA cells for instance). Severa factors can explain the phasic nature of L-ITCc response includinhibitory synaptic inputs to L-ITCcs, and/or the presence of short-term presynaptic inhibition of glutamate released onto L-ITCcs. This latter possibility is particularly intriguing because of the enrichment in mGlu7 and mGlu8 receptors of presynaptic fibers innervating mGlul $\alpha+$ L-ITCcs. Therefore, presynaptic group III mGlu receptors might control in time the activation of L-ITCcs upon noxious stimuli. To further support this idea, future work should investigate whether these receptors are selectively enriched in PIN terminals innervating L-ITCcs.

Here, we demonstrate that L-ITCcs are GABAergic. Despite an apparent conflict between our data and previous reports that large neurons associated with ITC clusters are devoid of visible somatic GABA immunolabeling in monkey (McDonald and Augustine, 1993), cat (Paré and Smith, 1993), and mouse (Busti et al., 2011), a highly efficient transport of GABA synthetic enzymes from the soma of mGlu $1 \alpha+$ L-ITCcs to their axon terminals may reconcile these findings. To further corroborate our finding in vivo, we also attempted to record from L-ITCcs in acute rat brain slices. However, our attempts have not been successful and none of the recorded and filled neurons was found to be mGlu $1 \alpha+$ or display morphology consistent with L-ITCcs. The lack of detection of L-ITCcs in vitro might be explained by several factors, including their relatively low abundance and a peculiar sensitivity of L-ITCcs to slicing, e.g., due to the extensive distribution of their dendritic and axonal branches. As a consequence, L-ITCcs may not display healthy somata in acute slices precluding their recording. Future experiments performed in transgenic rodents expressing a specific reporter for mGluR $1 \alpha+$ neurons should facilitate the detection of L-ITCcs in vitro and the elucidation of this issue.

Our data suggest that L-LTCcs represent a distinct neuron type compared with small-spiny ITCcs, consistent with previous anatomical data (Millhouse, 1986). The L-ITCcs display either 
none or a lower number of dendritic spines and a longer dendritic length, extending far beyond ITC clusters, compared with rat small-spiny ITCcs (Amir et al., 2011). Furthermore, the axon of L-ITCcs densely innervate the BLA and also reach the endopiriform nucleus, and the perirhinal and entorhinal cortices, whereas they avoided their parent intercalated region, in contrast to small-spiny ITCcs (Royer et al., 1999; Busti et al., 2011). The endopiriform nucleus and the entorhinal and perirhinal cortices are areas of convergence for both unimodal and complex polymodal information, and appear to be involved in the storage, consolidation or retrieval of emotional memories (de Curtis and Paré, 2004). Therefore, L-ITCcs are long-range projection neurons that may contribute to the synchronization of these areas with the amygdala to bind together multimodal or timing information in a single emotional memory.

Interestingly, we found that L-ITCcs targeted interneurons, most of which in the BLA appeared to be basket cells because they coexpressed PV and CB (Bienvenu et al., 2012). Because of their dense axonal arborization and targeting of interneurons, which in turn innervate hundreds of other neurons, L-ITCcs could have a profound and widespread disinhibitory influence on output neurons in the targeted areas, despite their relatively low number.

In view of their GABAergic nature, long dendrites, long-range projections, and widespread axonal arborization across several areas, L-ITCcs might act as "hub" cells (Bonifazi et al., 2009; Quilichini et al., 2012). Specifically, L-ITCcs may represent both "connector hubs" that display a long axon spanning across regions, and "provincial hubs" that display an extensive but local arborization pattern (Cossart, 2014). To our knowledge, no other GABAergic cell type in the amygdala displays the distinctive features of hub neurons. Hence, our characterization of L-ITCcs effectively broadens the understanding of GABAergic neuron diversity in the amygdala and highlights their potentially pivotal role in controlling network activities.

In conclusion, we show that L-ITCcs have unique morphological and neurochemical characteristics distinct from small-spiny ITCcs (Amir et al., 2011; Busti et al., 2011), are vigorously activated by noxious stimuli, are GABAergic, and innervate interneurons. Therefore, L-ITCcs are likely to transiently disinhibit principal cells and facilitate the integration of aversive nociceptive inputs with neutral sensory stimuli. Disinhibition of principal neurons by L-ITCcs following noxious stimuli in combination with a direct inhibition by axoaxonic cells (Bienvenu et al., 2012) may provide a discrete temporal window for associative synaptic plasticity. Because of their large dendritic field, selective targeting of local and distant interneurons, we speculate that L-ITCcs coordinate distributed networks to bind sensory information into individual memories.

\section{Notes}

Supplemental material for this article is available at http://www.mrc.ox. ac.uk/itc-movie. Movie 1 shows a 3-D reconstruction of L-ITCc TJX-31. This material has not been peer reviewed.

\section{References}

Amano T, Unal CT, Paré D (2010) Synaptic correlates of fear extinction in the amygdala. Nat Neurosci 13:489-494. CrossRef Medline

Amir A, Amano T, Paré D (2011) Physiological identification and infralimbic responsiveness of rat intercalated amygdala neurons. J Neurophysiol 105:3054-3066. CrossRef Medline

Andrioli A, Alonso-Nanclares L, Arellano JI, DeFelipe J (2007) Quantitative analysis of parvalbumin-immunoreactive cells in the human epileptic hippocampus. Neuroscience 149:131-143. CrossRef Medline

Benke D, Cicin-Sain A, Mertens S, Mohler H (1991) Immunochemical iden- tification of the alpha 1- and alpha 3-subunits of the GABAA-receptor in rat brain. J Recept Res 11:407-424. Medline

Bienvenu TC, Busti D, Magill PJ, Ferraguti F, Capogna M (2012) Cell-typespecific recruitment of amygdala interneurons to hippocampal theta rhythm and noxious stimuli in vivo. Neuron 74:1059-1074. CrossRef Medline

Bonifazi P, Goldin M, Picardo MA, Jorquera I, Cattani A, Bianconi G, Represa A, Ben-Ari Y, Cossart R (2009) GABAergic hub neurons orchestrate synchrony in developing hippocampal networks. Science 326:1419-1424. CrossRef Medline

Busti D, Geracitano R, Whittle N, Dalezios Y, Mańko M, Kaufmann W, Sätzler K, Singewald N, Capogna M, Ferraguti F (2011) Different fear states engage distinct networks within the intercalated cell clusters of the amygdala. J Neurosci 31:5131-5144. CrossRef Medline

Caillard O, Moreno H, Schwaller B, Llano I, Celio MR, Marty A (2000) Role of the calcium-binding protein parvalbumin in short-term synaptic plasticity. Proc Natl Acad Sci U S A 97:13372-13377. CrossRef Medline

Capogna M (2014) GABAergic cell type diversity in the basolateral amygdala. Curr Opin Neurobiol 26:110-116. CrossRef Medline

Clement EA, Richard A, Thwaites M, Ailon J, Peters S, Dickson CT (2008) Cyclic and sleep-like spontaneous alternations of brain state under urethane anaesthesia. PLoS One 3:e2004. CrossRef Medline

Coizet V, Dommett EJ, Redgrave P, Overton PG (2006) Nociceptive responses of midbrain dopaminergic neurones are modulated by the superior colliculus in the rat. Neuroscience 139:1479-1493. CrossRef Medline

Collins DR, Paré D (1999) Spontaneous and evoked activity of intercalated amygdala neurons. Eur J Neurosci 11:3441-3448. CrossRef Medline

Cossart R (2014) Operational hub cells: a morpho-physiologically diverse class of GABAergic neurons united by a common function. Curr Opin Neurobiol 26:51-56. CrossRef Medline

Courtin J, Karalis N, Gonzalez-Campo C, Wurtz H, Herry C (2014) Persistence of amygdala gamma oscillations during extinction learning predicts spontaneous fear recovery. Neurobiol Learn Mem 113:82-89. CrossRef Medline

de Curtis M, Paré D (2004) The rhinal cortices: a wall of inhibition between the neocortex and the hippocampus. Prog Neurobiol 74:101-110. CrossRef Medline

Dias BG, Banerjee SB, Goodman JV, Ressler KJ (2013) Towards new approaches to disorders of fear and anxiety. Curr Opin Neurobiol 23:346352. CrossRef Medline

Dobi A, Sartori SB, Busti D, Van der Putten H, Singewald N, Shigemoto R, Ferraguti F (2013) Neural substrates for the distinct effects of presynaptic group III metabotropic glutamate receptors on extinction of contextual fear conditioning in mice. Neuropharmacology 66:274-289. CrossRef Medline

Doig NM, Moss J, Bolam JP (2010) Cortical and thalamic innervation of direct and indirect pathway medium-sized spiny neurons in mouse striatum. J Neurosci 30:14610-14618. CrossRef Medline

Duvarci S, Paré D (2014) Amygdala microcircuits controlling learned fear. Neuron 82:966-980. CrossRef Medline

Ehrlich I, Humeau Y, Grenier F, Ciocchi S, Herry C, Lüthi A (2009) Amygdala inhibitory circuits and the control of fear memory. Neuron 62:757-771. CrossRef Medline

Ferraguti F, Cobden P, Pollard M, Cope D, Shigemoto R, Watanabe M, Somogyi P (2004) Immunolocalization of metabotropic glutamate receptor 1a (mGluRla) in distinct classes of interneuron in the CA1 region of the rat hippocampus. Hippocampus 14:193-215. CrossRef Medline

Ferraguti F, Klausberger T, Cobden P, Baude A, Roberts JD, Szucs P, Kinoshita A, Shigemoto R, Somogyi P, Dalezios Y (2005) Metabotropic glutamate receptor 8-expressing nerve terminals target subsets of GABAergic neurons in the hippocampus. J Neurosci 25:10520-10536. CrossRef Medline

Fritschy JM, Benke D, Mertens S, Oertel WH, Bachi T, Möhler H (1992) Five subtypes of type A gamma-aminobutyric acid receptors identified in neurons by double and triple immunofluorescence staining with subunitspecific antibodies. Proc Natl Acad Sci U S A 89:6726-6730. CrossRef Medline

Fuentealba P, Begum R, Capogna M, Jinno S, Márton LF, Csicsvari J, Thomson A, Somogyi P, Klausberger T (2008) Ivy cells: a population of nitric-oxide-producing, slow-spiking GABAergic neurons and their involvement in hippocampal network activity. Neuron 57:917-929. CrossRef Medline 
Garbelli R, Inverardi F, Medici V, Amadeo A, Verderio C, Matteoli M, Frassoni C (2008) Heterogeneous expression of SNAP-25 in rat and human brain. J Comp Neurol 506:373-386. CrossRef Medline

Geracitano R, Kaufmann WA, Szabo G, Ferraguti F, Capogna M (2007) Synaptic heterogeneity between mouse paracapsular intercalated neurons of the amygdala. J Physiol 585:117-134. CrossRef Medline

Gross A, Sims RE, Swinny JD, Sieghart W, Bolam JP, Stanford IM (2011) Differential localization of GABA(A) receptor subunits in relation to rat striatopallidal and pallidopallidal synapses. Eur J Neurosci 33:868-878. CrossRef Medline

Gross CT, Canteras NS (2012) The many paths to fear. Nat Rev Neurosci 13:651-658. CrossRef Medline

Ichikawa R, Yamasaki M, Miyazaki T, Konno K, Hashimoto K, Tatsumi H, Inoue Y, Kano M, Watanabe M (2011) Developmental switching of perisomatic innervation from climbing fibers to basket cell fibers in cerebellar Purkinje cells. J Neurosci 31:16916-16927. CrossRef Medline

Isomura Y, Harukuni R, Takekawa T, Aizawa H, Fukai T (2009) Microcircuitry coordination of cortical motor information in self-initiation of voluntary movements. Nat Neurosci 12:1586-1593. CrossRef Medline

Jüngling K, Seidenbecher T, Sosulina L, Lesting J, Sangha S, Clark SD, Okamura N, Duangdao DM, Xu YL, Reinscheid RK, Pape HC (2008) Neuropeptide S-mediated control of fear expression and extinction: role of intercalated GABAergic neurons in the amygdala. Neuron 59:298-310. CrossRef Medline

Klausberger T, Magill PJ, Márton LF, Roberts JD, Cobden PM, Buzsáki G, Somogyi P (2003) Brain-state- and cell-type-specific firing of hippocampal interneurons in vivo. Nature 421:844-848. CrossRef Medline

Lasztóczi B, Tukker JJ, Somogyi P, Klausberger T (2011) Terminal field and firing selectivity of cholecystokinin-expressing interneurons in the hippocampal CA3 area. J Neurosci 31:18073-18093. CrossRef Medline

LeDoux JE (2000) Emotion circuits in the brain. Annu Rev Neurosci 23: 155-184. CrossRef Medline

Likhtik E, Popa D, Apergis-Schoute J, Fidacaro GA, Paré D (2008) Amygdala intercalated neurons are required for expression of fear extinction. Nature 454:642-645. CrossRef Medline

Linke R, Braune G, Schwegler H (2000) Differential projection of the posterior paralaminar thalamic nuclei to the amygdaloid complex in the rat. Exp Brain Res 134:520-532. CrossRef Medline

Liu S, Qu MH, Ren W, Hu HZ, Gao N, Wang GD, Wang XY, Fei G, Zuo F, Xia Y, Wood JD (2008) Differential expression of canonical (classical) transient receptor potential channels in guinea pig enteric nervous system. J Comp Neurol 511:847-862. CrossRef Medline

Mańko M, Geracitano R, Capogna M (2011) Functional connectivity of the main intercalated nucleus of the mouse amygdala. J Physiol 589:19111925. CrossRef Medline

McDonald AJ, Augustine JR (1993) Localization of GABA-like immunoreactivity in the monkey amygdala. Neuroscience 52:281-294. CrossRef Medline

Megías M, Emri Z, Freund TF, Gulyás AI (2001) Total number and distribution of inhibitory and excitatory synapses on hippocampal CA1 pyramidal cells. Neuroscience 102:527-540. CrossRef Medline

Millhouse OE (1986) The intercalated cells of the amygdala. J Comp Neurol 247:246-271. CrossRef Medline

Nakaya Y, Kaneko T, Shigemoto R, Nakanishi S, Mizuno N (1994) Immunohistochemical localization of substance $\mathrm{P}$ receptor in the central nervous system of the adult rat. J Comp Neurol 347:249-274. Medline
Pape HC, Paré D (2010) Plastic synaptic networks of the amygdala for the acquisition, expression, and extinction of conditioned fear. Physiol Rev 90:419-463. CrossRef Medline

Paré D, Gaudreau H (1996) Projection cells and interneurons of the lateral and basolateral amygdala: distinct firing patterns and differential relation to theta and delta rhythms in conscious cats. J Neurosci 16:3334-3350. Medline

Paré D, Smith Y (1993) Distribution of GABA immunoreactivity in the amygdaloid complex of the cat. Neuroscience 57:1061-1076. CrossRef Medline

Paxinos G, Watson C (2007) The rat brain in stereotaxic coordinates. San Diego: Academic.

Pinault D (1996) A novel single-cell staining procedure performed in vivo under electrophysiological control: morpho-functional features of juxtacellularly labeled thalamic cells and other central neurons with biocytin or neurobiotin. J Neurosci Methods 65:113-136. CrossRef Medline

Quilichini PP, Le Van Quyen M, Ivanov A, Turner DA, Carabalona A, Gozlan H, Esclapez M, Bernard C (2012) Hub GABA neurons mediate gammafrequency oscillations at ictal-like event onset in the immature hippocampus. Neuron 74:57-64. CrossRef Medline

Royer S, Martina M, Paré D (1999) An inhibitory interface gates impulse traffic between the input and output stations of the amygdala. J Neurosci 19:10575-10583. Medline

Royer S, Martina M, Paré D (2000) Polarized synaptic interactions between intercalated neurons of the amygdala. J Neurophysiol 83:3509-3518. Medline

Shigemoto R, Kinoshita A, Wada E, Nomura S, Ohishi H, Takada M, Flor PJ, Neki A, Abe T, Nakanishi S, Mizuno N (1997) Differential presynaptic localization of metabotropic glutamate receptor subtypes in the rat hippocampus. J Neurosci 17:7503-7522. Medline

Siapas AG, Lubenov EV, Wilson MA (2005) Prefrontal phase locking to hippocampal theta oscillations. Neuron 46:141-151. CrossRef Medline

Sperk G, Widmann R (1985) Somatostatin precursor in the rat striatum: Changes after local injection of kainic acid. J Neurochem 45:1441-1447. Medline

Sreepathi HK, Ferraguti F (2012) Subpopulations of neurokinin 1 receptorexpressing neurons in the rat lateral amygdala display a differential pattern of innervation from distinct glutamatergic afferents. Neuroscience 203:59-77. CrossRef Medline

Tanaka J, Nakagawa S, Kushiya E, Yamasaki M, Fukaya M, Iwanaga T, Simon MI, Sakimura K, Kano M, Watanabe M (2000) Gq protein alpha subunits Galphaq and Galpha11 are localized at postsynaptic extrajunctional membrane of cerebellar Purkinje cells and hippocampal pyramidal cells. Eur J Neurosci 12:781-792. CrossRef Medline

Tukker JJ, Fuentealba P, Hartwich K, Somogyi P, Klausberger T (2007) Cell type-specific tuning of hippocampal interneuron firing during gamma oscillations in vivo. J Neurosci 27:8184-8189. CrossRef Medline

Wang HL, Morales M (2009) Pedunculopontine and laterodorsal tegmental nuclei contain distinct populations of cholinergic, glutamatergic and GABAergic neurons in the rat. Eur J Neurosci 29:340-358. CrossRef Medline

Whittle N, Hauschild M, Lubec G, Holmes A, Singewald N (2010) Rescue of impaired fear extinction and normalization of corticoamygdala circuit dysfunction in a genetic mouse model by dietary zinc restriction. J Neurosci 30:13586-13596. CrossRef Medline 